\title{
A Global Review of PWR Nuclear Power Plants
}

\author{
Pablo Fernández-Arias ${ }^{1, *}$, Diego Vergara ${ }^{1}\left(\mathbb{C}\right.$ and José A. Orosa ${ }^{2}(\mathbb{C}$ \\ 1 Department of Mechanical Engineering, Catholic University of Ávila, C/Canteros, s/n, 05005 Avila, Spain; \\ diego.vergara@ucavila.es \\ 2 Department of N. S. and Marine Engineering, Universidade da Coruña, Paseo de Ronda, 51, \\ 15011 A Coruña, Spain; jose.antonio.orosa@udc.es \\ * Correspondence: pablo.fernandezarias@ucavila.es; Tel.: +34-920-251-020
}

Received: 3 June 2020; Accepted: 25 June 2020; Published: 27 June 2020

Featured Application: This work shows a global review with three analyses of the PWR nuclear design: (i) technical evolution; (ii) level of implementation in the world, and (iii) life extension scenario.

\begin{abstract}
Nuclear energy is presented as a real option in the face of the current problem of climate change and the need to reduce $\mathrm{CO}_{2}$ emissions. The nuclear reactor design with the greatest global impact throughout history and which has the most ambitious development plans is the Pressurized Water Reactor (PWR). Thus, a global review of such a reactor design is presented in this paper, utilizing the analysis of (i) technical aspects of the different variants of the PWR design implemented over the past eight years, (ii) the level of implementation of PWR nuclear power plants in the world, and (iii) a life extension scenario and future trends in PWR design based on current research and development (R\&D) activity. To develop the second analysis, a statistical study of the implementation of the different PWR variants has been carried out. Such a statistical analysis is based on the operating factor, which represents the relative frequency of reactors operating around the world. The results reflect the hegemony of the western variants in the 300 reactors currently operating, highlighting the North American and French versions. Furthermore, a simulation of a possible scenario of increasing the useful life of operational PWRs up to 60 years has been proposed, seeing that in 2050 the generation capacity of nuclear PWRs power plants will decrease by $50 \%$, and the number of operating reactors by $70 \%$.
\end{abstract}

Keywords: nuclear energy; power; pressurized water reactor; operating factor

\section{Introduction}

Currently, due to the growing demand for energy worldwide, nuclear energy has regained the relevant role it played throughout the past 20th century, as an alternative to $\mathrm{CO}_{2}$-emitting electric power generation technologies. This generation technology presently accounts for $10 \%$ of the electrical energy generated in the world. Over the past eighty years, various nuclear reactor designs have been developed around the world, which can be classified according to (i) their configuration and objectives, or (ii) their generation stage. Within the first classification, it is necessary to distinguish between (i) fast reactors and (ii) thermal reactors. The first ones, fast factors, are capable of generating more fissile material than they have consumed. On the other hand, among thermal reactors there are several combinations of moderators - in charge of reducing neutron energy-and coolants-the fluid that transmits the heat generated in the reactor-that have been successfully developed in different nuclear reactor designs.

The second classification (thermal reactors) is the most used [1-3] and allows defining the following generations of nuclear reactors (Figure 1): Generation I: prototypes built between 1957 and 
1963; Generation II: commercial production, built from the mid-1960s onward; Generation III: advanced reactors-safer and with greater generation capacity, built since the early nineties; Generation III+: nuclear reactors with structural safeguards and/or passive safety features, designed from the 21st century; and finally Generation IV: the highly efficient reactors of the future, with advanced safety features and generating small amount of spent nuclear fuel.

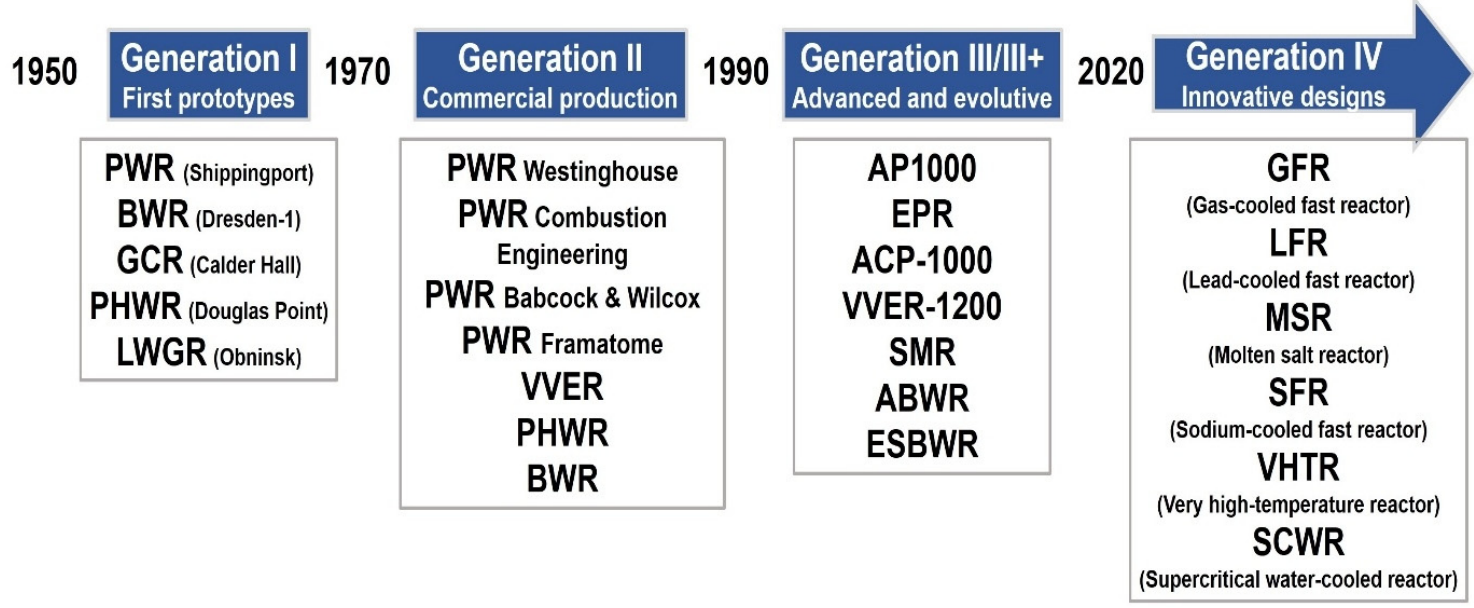

Figure 1. Generations of nuclear reactors throughout the past seventy years.

Throughout history, the most developed nuclear reactor designs have been Generation II (Figure 2), with different fundamental characteristics [4-6]: (i) PWR (pressurized water reactor): in whose vessel the coolant does not reach boiling temperature. It developed from the 1950s; (ii); BWR (boiling water reactor): uses light water as moderator and coolant. It developed like the PWR from the 1950s; (iii) PHWR (pressurized heavy water reactor): in which heavy water-deuterium dioxide, D20—was incorporated as moderator and coolant. It was developed in Canada from the sixties; and (iv) GCR (gas cooled reactor): the reactor design that uses graphite as a moderator and gas as a coolant. It was developed in the UK after World War II. Table 1 summarizes the main characteristics of these four designs (PWR, BWR, PHWR, and GCR), as they are the most important within Generation II.

Furthermore, in this group of Generation II reactors, there is another design known as LWGR (light water graphite reactor) or RBMK in its Soviet variant, from the Russian Reaktor Bolshoy Moshchnosty Kanalny. This latest RBMK design is known to be the one that caused the fatal accident at the Chernobyl nuclear power plant (Ukraine) in 1986. The RBMK design is very different from the rest of the power reactors, since it is used simultaneously for both the production of plutonium as for the production of electrical energy.

The basis for the data research on Nuclear Power Reactors is the Power Reactor Information System (PRIS) database from the International Atomic Energy Agency (IAEA) [6]. Other authors have taken data from this database for their research in nuclear science $[7,8]$. To study the obtained data, a parameter called operating factor $(\mathrm{OF})$ has been used in this paper, which is defined as the relative frequency of PWR reactors operating around the world (in percentage):

$$
\mathrm{OF}=\frac{n_{i}}{N} \cdot 100
$$

where $n_{i}$ is the number of a specific PWR design $i$, and $N$ the total population of operating PWR in the world ( $N=300$ currently, according to [6]).

It is worth noting that the parameter OF is different from that known as the operation factor, which is defined by IAEA as the ratio of the number of hour the unit was on-line to the total number of hours in the reference period, expressed as a percentage [6]. 
The 447 nuclear reactors operating in the world as of January 2020 are distributed as follows: (i) PWR: 300 operating reactors, representing $67 \%$ of the operating nuclear reactors and an electric power generation capacity of $284 \mathrm{GWe}$; (ii) BWR: 69 operating units, representing 16\% of the total and an electrical power generation capacity of $69 \mathrm{GWe}$; (iii) PHWR: 48 operating units, representing 10\% of the total and a capacity of $24 \mathrm{GWe}$; (iv) other designs: the remaining $7 \%$ of the operating nuclear reactors in the world are capable of generating $17 \mathrm{GWe}$, among which are different designs such as GCR and LWGR (Figure 3). It should be noted that these data correspond to January 2020 and that they may vary from the current ones depending on (i) the start-up of a reactor that was previously under construction or (ii) if there has been a permanent shutdown of a reactor that was in operation.

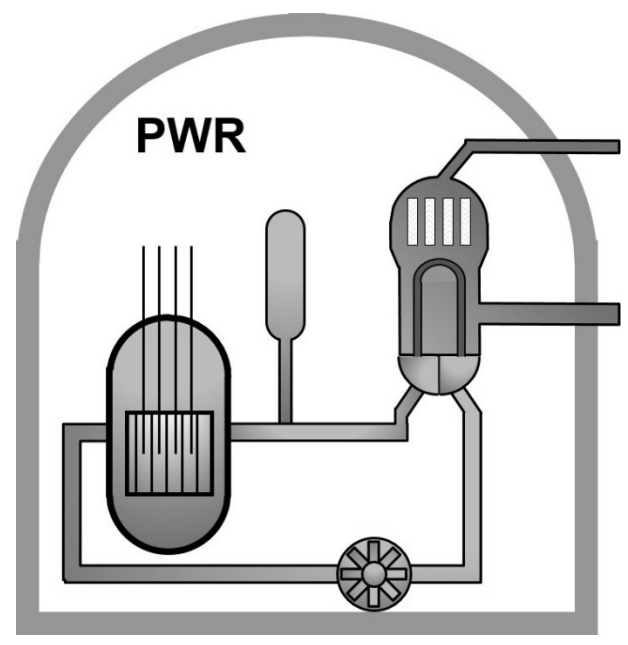

(a)

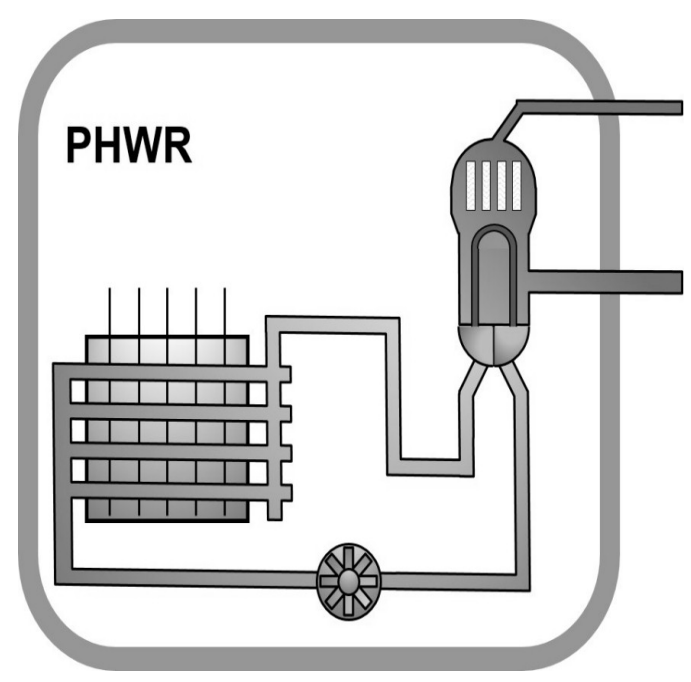

(c)

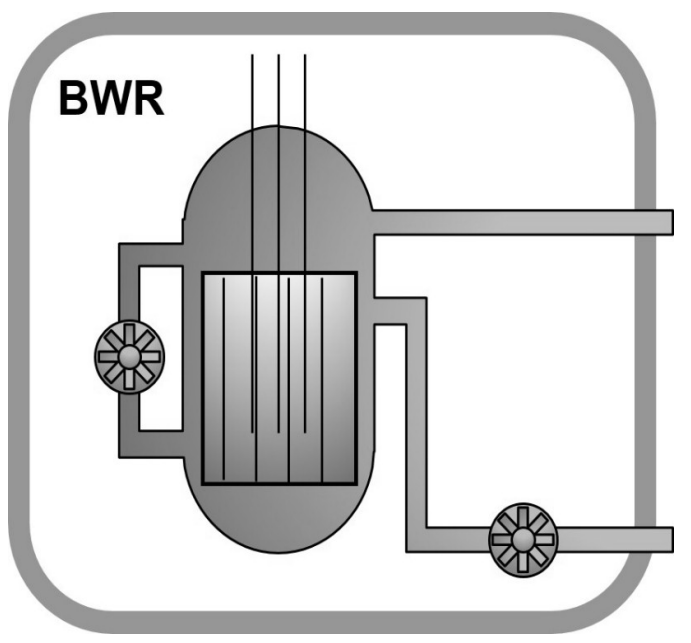

(b)

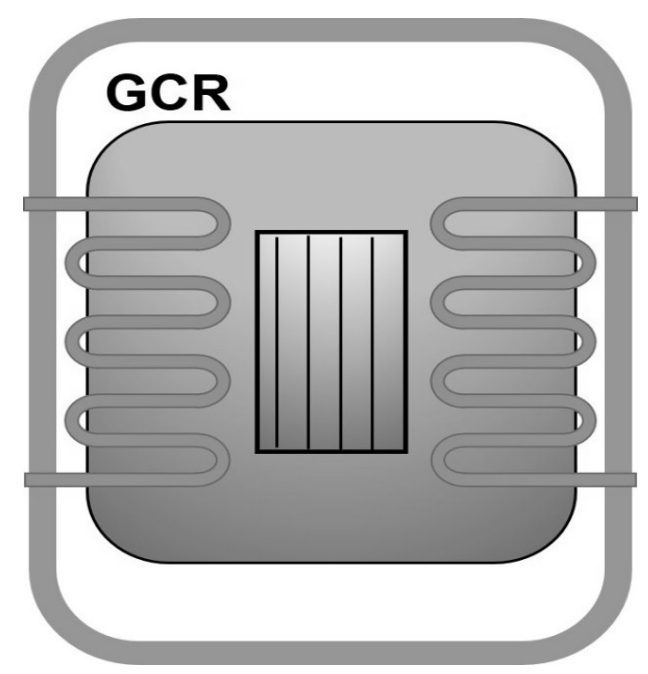

(d)

Figure 2. Generation II designs: (a) Pressurized Water Reactor (PWR); (b) Boiling Water Reactor (BWR); (c) Pressurized Heavy Water Reactor (PHWR); and (d) Gas Cooled Reactor (GCR).

Among the 300 PWR nuclear reactors currently operating in the world [6], there are several design variants. To obtain a safer and more efficient PWR reactor, the different components of this technical system have been taking different forms over time due to various technical factors (performance, safety, availability). Thus, several references have dealt with the evolution of nuclear reactor designs 
globally, analyzing the different factors modified in different generations [9-11]. Besides, other authors discussed the evolution of the PWR design throughout the different Generations [12-14] and other references developed the technical evolution of aspects of the PWR design as relevant as control rods or fuel $[5,15,16]$. Given these results, it can be assured that the PWR design: (i) is that which currently has the highest implementation percentage (67\%) in the world (Figure 3); and (ii) has given rise to different variants depending on various technical factors.

Table 1. Main characteristics of the Generation II designs.

\begin{tabular}{|c|c|c|c|c|}
\hline \multirow{2}{*}{ Main Characteristics } & \multicolumn{4}{|c|}{ Generation II Designs } \\
\hline & PWR & BWR & PHWR & GCR \\
\hline Country of development & $\begin{array}{l}\text { United States, Germany, } \\
\text { France, Japan, South } \\
\text { Korea and Russia }\end{array}$ & United States and Japan & Canada & United Kingdom \\
\hline Fuel & $\begin{array}{c}\text { Enriched Uranium } \\
(<3.5 \% \text { U-235) }\end{array}$ & $\begin{array}{l}\text { Enriched Uranium } \\
\quad(<3.5 \% \text { U-235) }\end{array}$ & $\begin{array}{l}\text { Natural Uranium } \\
\left(\mathrm{UO}_{2} \text { natural }\right)\end{array}$ & $\begin{array}{l}\text { Natural Uranium } \\
(<0.7 \% \text { U-235) }\end{array}$ \\
\hline Coolant & $\begin{array}{l}\text { Water } \\
\left(\mathrm{H}_{2} \mathrm{O}\right)\end{array}$ & $\begin{array}{l}\text { Water } \\
\left(\mathrm{H}_{2} \mathrm{O}\right)\end{array}$ & $\begin{array}{l}\text { Heavy Water } \\
\left(\mathrm{D}_{2} \mathrm{O}\right)\end{array}$ & $\mathrm{CO}_{2}$ \\
\hline Moderator & $\begin{array}{l}\text { Water } \\
\left(\mathrm{H}_{2} \mathrm{O}\right)\end{array}$ & $\begin{array}{l}\text { Water } \\
\left(\mathrm{H}_{2} \mathrm{O}\right)\end{array}$ & $\begin{array}{l}\text { Heavy Water } \\
\left(\mathrm{D}_{2} \mathrm{O}\right)\end{array}$ & Graphite \\
\hline
\end{tabular}

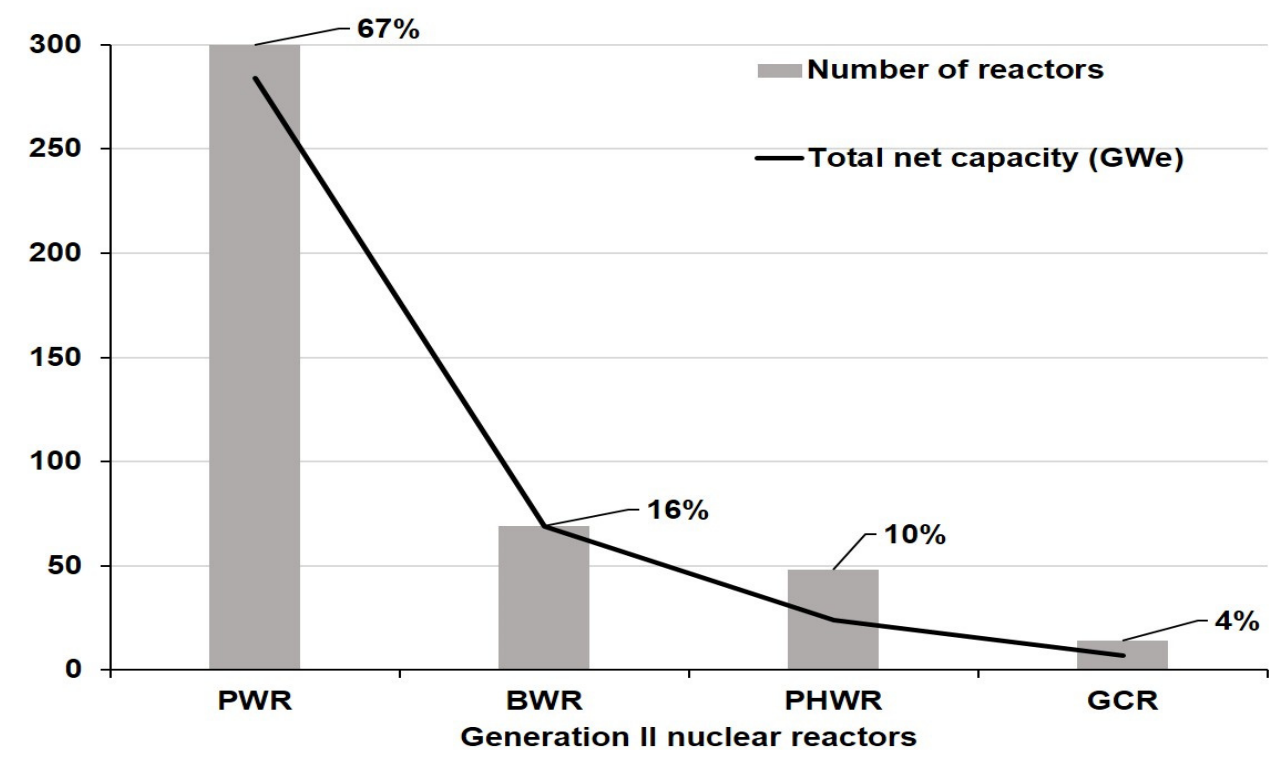

Figure 3. Operative reactors in the world (data collected from [6] in January 2020).

From a simple consultation in SCOPUS on the number of articles that include, in the title, abstract, or keywords, the names of Generation II designs (PWR, BWR, PHWR, and GCR), Figure 4 was obtained. Thus, a total of 22,457 papers in the SCOPUS database include the denomination of the Generation II designs (data collected in April 2020). Among this criterion, 11,762 (around 52\%) of the total published papers include "PWR" or "pressurized water reactor", so this design gets the highest number of papers among Generation II nuclear reactors. On the other hand, approximately one half $(48 \%)$ of the published research papers are linked with the rest of Generation II designs. In this group, 6341 papers containing "BWR or "boiling water reactor" (approximately 28\%); 958 papers containing "PHWR" or "pressurized heavy water reactor" (around 4\%); and 3396 papers containing "GCR" or "gas-cooled reactor" (around 15\%) in the title, abstract or keywords. It should be emphasized here that the GCR design exhibits a higher scientific interest than expected, since its OP is only $4 \%$ in the world (Figure 3). This may be due to the GCR nuclear power plants are mainly concentrated in the United Kingdom - where this nuclear reactor design was developed. In this country, approximately 
$93 \%$ of the operational reactors are GCR (14 GCR nuclear power plants) and $71 \%$ of the total permanent shutdown reactors are also GCR. Therefore, nuclear scientific research in this country is specialized and focused on GCR design.

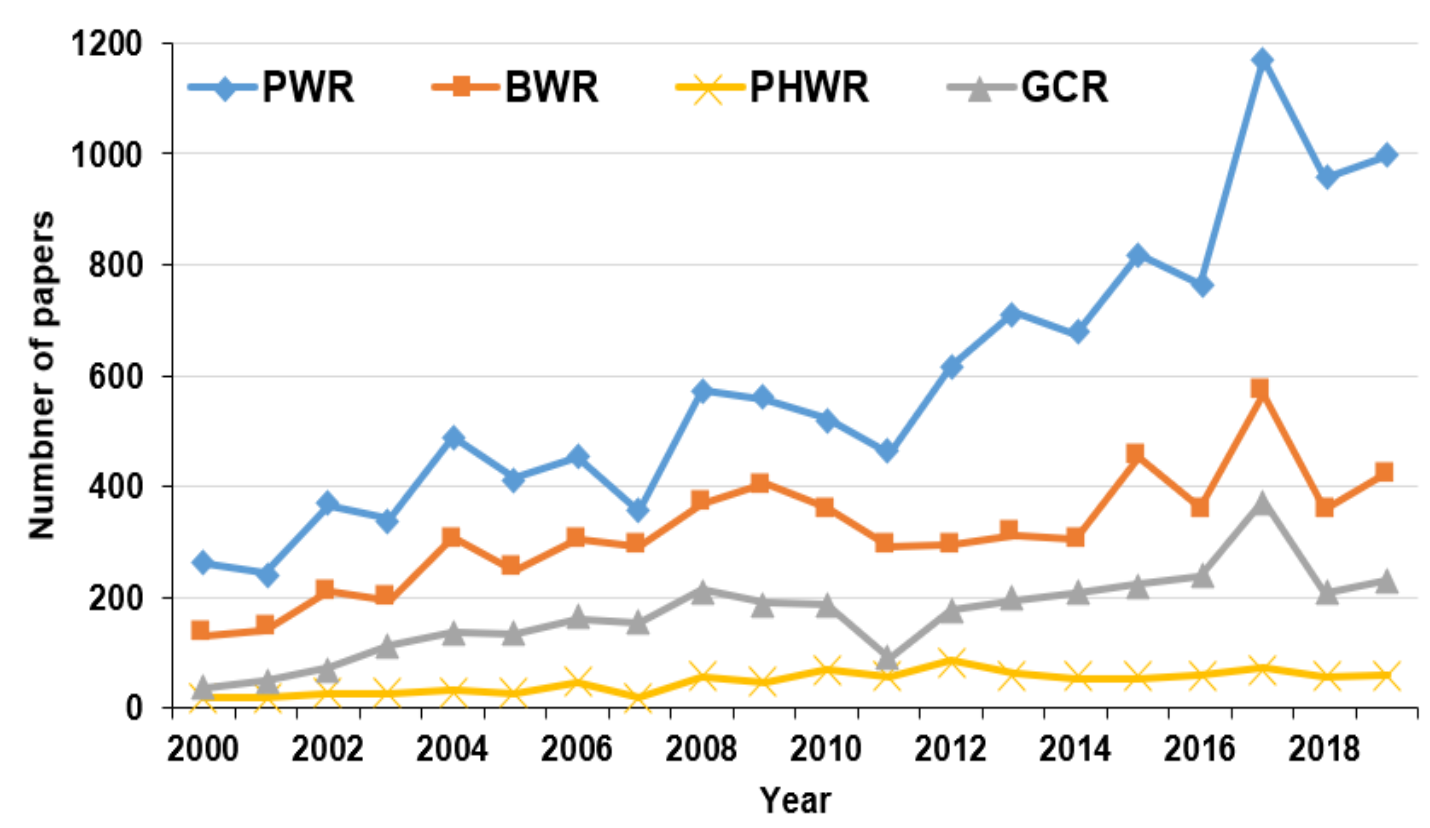

Figure 4. Number of research papers indexed in SCOPUS related with the Generation II designs (data collected on April 2020).

Taking into account the data exposed in Figures 3 and 4, which indicate the scientific interest in PWR nuclear design, the objectives of this article are to analyze both (i) the technical evolution and (ii) the different expansion mechanisms and the OP of the different variants of the PWR nuclear reactor design developed in all Generations (Generation II, Generation III, and Generation III+). The analysis carried out in this article focuses on the nations that have the most developed nuclear energy as a source of electricity generation: the United States, France, Russia, and China.

\section{International Development of the PWR Design}

This section shows the study of the technological development of the PWR design. For this, it is necessary initially to understand the operation of a nuclear power plant with a PWR reactor, and from that moment, to analyze the different variants that have been made of this design. Thus, in this chapter the North American variants are first developed, carried out by the companies Westinghouse, Babcock $\mathcal{E}$ Wilcox, and Combustion Engineering. Later, the variants designed by the French company Framatome are explained. To continue the study, the different variants of the Soviet version of the PWR design, called VVER, developed by the Rosatom Company are developed. Finally, Chinese design variants, designed by China General Nuclear Power Corporation (CGN) and China National Nuclear Corporation (CNNC), are studied.

\subsection{Operation of a PWR Nuclear Power Plant}

Nuclear power plants operate for the same purpose as a thermal power station: to convert the heat generated into electricity. Its operating principle is also the same: the use of a fuel that enables water vapor to be obtained, which is used in a turbine to transform its heat output into rational speed and, in turn, into an electrical output voltage for the alternator. In the fuel is just where the fundamental difference between both technologies lies. While thermal power plants use fossil fuels, nuclear power plants use fissile fuel that enables a fission chain reaction to be obtained. In a PWR design nuclear 
power plant there are three cooling circuits (Figure 5): (i) primary circuit; (ii) secondary circuit or steam cycle; and (iii) tertiary circuit [17].

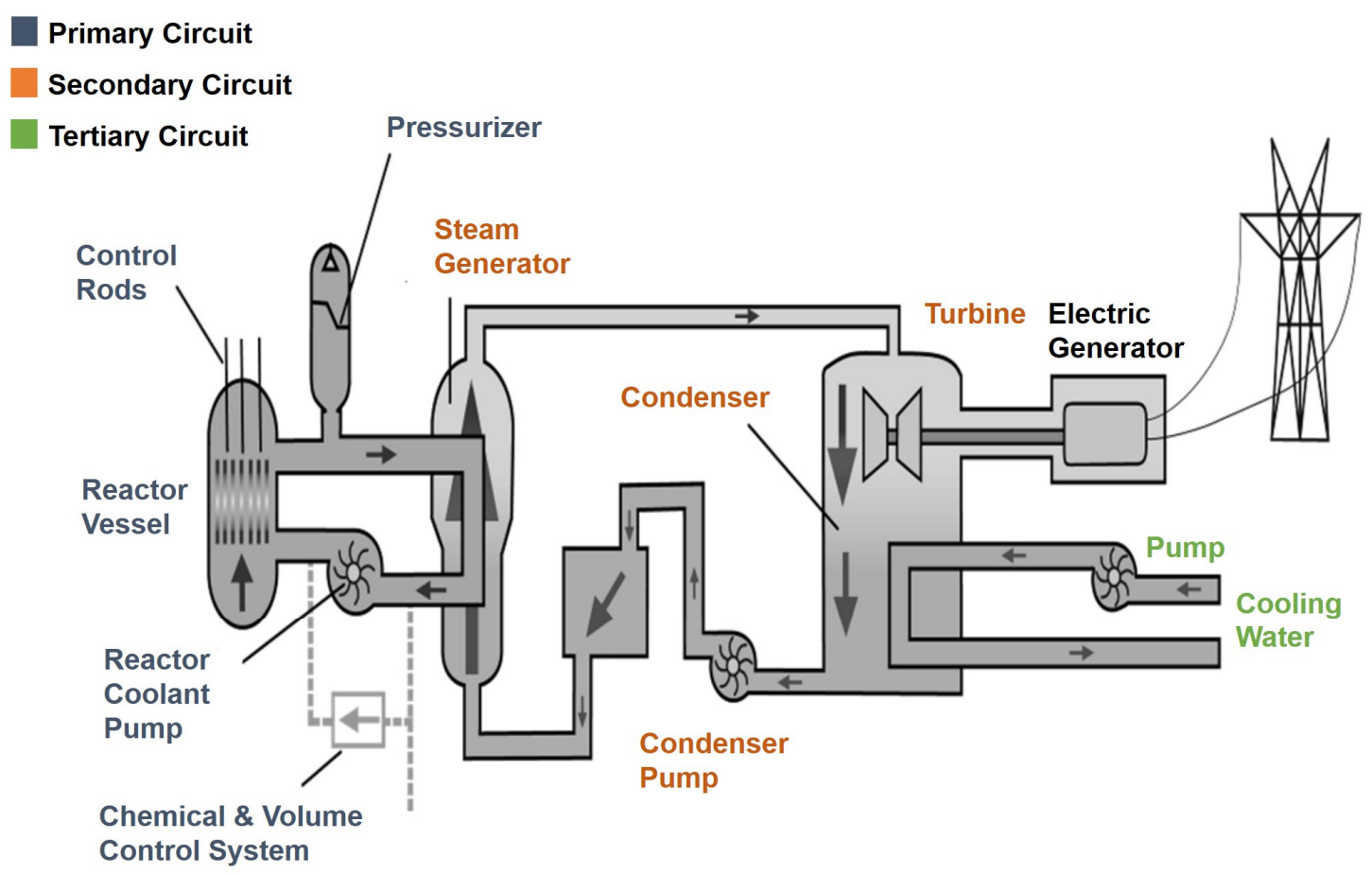

Figure 5. PWR layout and main circuits.

Until now, pending the commercial application of nuclear fusion, within the vessels of the different designs developed in the successive Generations (Figure 2), the process of division of the atomic nuclei (nuclear fission) takes place, causing the increase in temperature of the coolant that circulates initially around the cladding of the fuel elements and later through a closed circuit, called the primary circuit. The reactor vessel is the main component of this circuit, also called the coolant system reactor (RCS).

Each primary circuit is made up of the pipes necessary to maintain the coolant, a reactor coolant pump (RCP) and a heat exchanger called a Steam Generator (SG). The pressurizer is installed in one of these primary circuits, a component in charge of controlling the process pressure (Figure 6). The primary circuit is around 150 bars of pressure and $300{ }^{\circ} \mathrm{C}$ of temperature, so the water does not reach its boiling point, thus avoiding the formation of bubbles that would hinder the transfer of pod-coolant heat. If there was no cooling focus, the temperature of the coolant could continue to increase over time.

Making an everyday simile, the PWR design vessel behaves like a pot express. The fuel elements inside the vessel heat the water, while in the express pot the fire is in charge of heating the water inside. To prevent the temperature from continuing to rise over time, a cold focus is designed through which the coolant contained in the primary circuit can be cooled so that it returns to the reactor vessel and is again heated as a consequence of the transfer of heat between the coolant and the fuel elements.

In the pressure cooker, the cold focus is the release of steam to the outside through the discharge valve. In the PWR design, the cold focus is the steam generator, which has two goals: (i) to act as a barrier between the primary and secondary circuits, and (ii) to transform the thermal energy generated in the reactor into latent energy utilizing steam generated. This steam is led through the secondary circuit to the different turbines and the electric generator, in charge of converting the shaft rotation energy into electrical energy, a process similar to that performed by a dynamo on a bicycle.

The steam used in the turbines goes back to a liquid state in the condenser, thanks to the cooling originated in this component by a tertiary circuit. Once this steam has condensed, it is used again as feed water in the steam generator. Finally, the heat transferred in the condenser to the water used in 
the tertiary circuit is evacuated to the outside through a cold focus, either in the form of a reservoir, river or cooling towers (Figure 5).

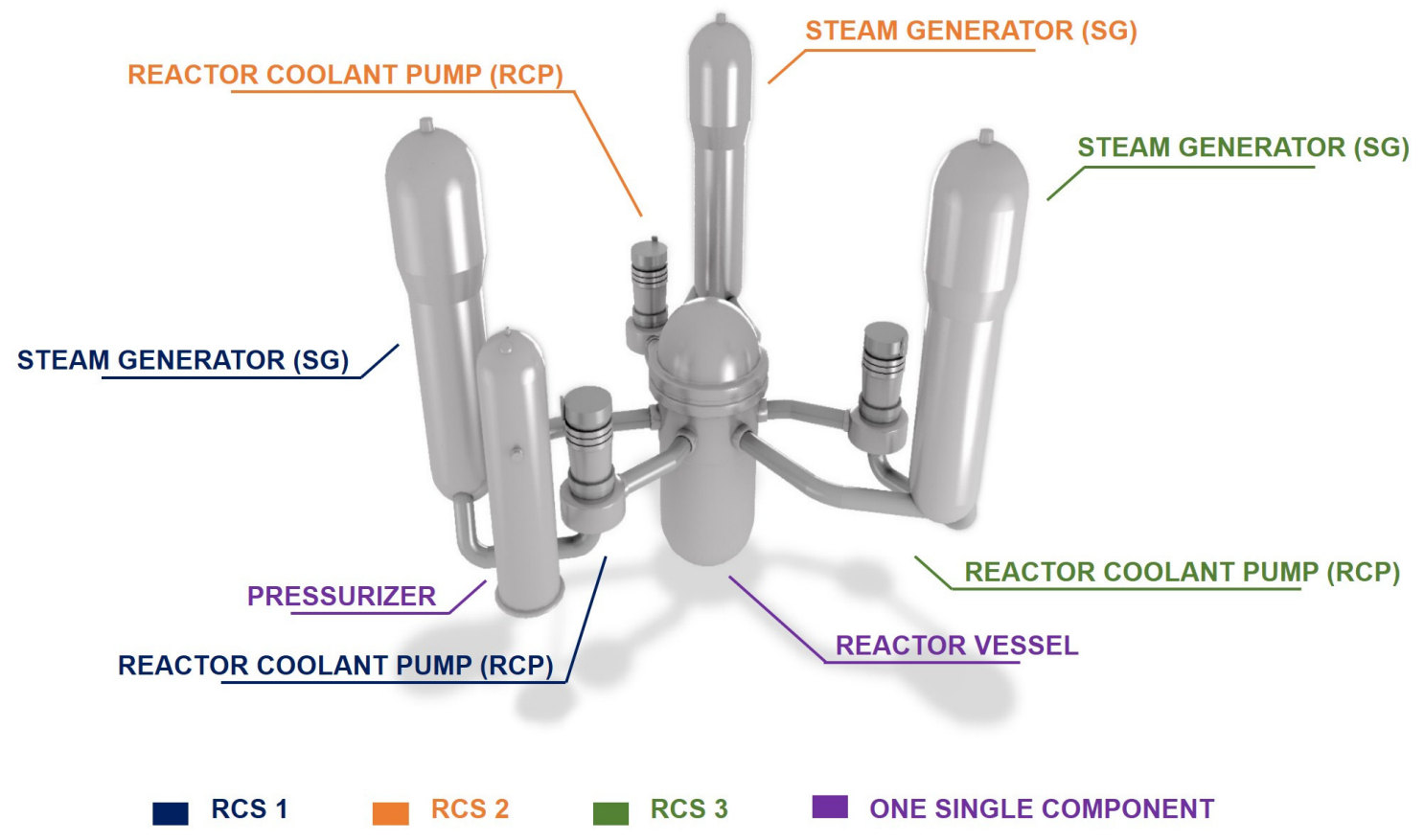

Figure 6. A 3D view of a PWR design with RCS and main components.

\subsection{American PWR Evolution}

Although the United States also developed the BWR design across different generations, the PWR design has been the one with the highest OP (Figure 3). In the 1950s, PWR design became the preferred choice when developing a nuclear-powered armada. Subsequently, the country's first nuclear power plant, Shippingport, with a PWR reactor inside, was the origin of the most powerful nuclear reactor design to date. In fact, its reactor served as a reference to those built and later used in the United States and to those exported by North American companies [3,18,19].

Given the high growth expectations of the US nuclear industry, the companies Babcock $\mathcal{E}$ Wilcox $(\mathrm{B} \& W)$ and Combustion Engineering (CE), initially focused on the manufacture of the main components of Westinghouse's BWR and BWR nuclear reactor designs by General Electric, joined the nuclear race with the development of their own PWR reactor designs [13].

The different variants of the PWR nuclear reactor design developed from the 1960s by these three US companies are described below: (i) Westinghouse, (ii) Babcock \& Wilcox, and (iii) Combustion Engineering.

\subsubsection{Westinghouse PWR Design}

After checking the technical feasibility of the technology at Shippingport, it began its commercial development. Two new nuclear power plants, Connecticut Yankee and San Onofre, began commercial operation in 1968 and featured a PWR design supplied by the Westinghouse Company under a turnkey contract [20]. In the case of the Connecticut Yankee nuclear power plant, a 4-loop PWR design and a generation capacity of 490 MWe were chosen (Figure 7d). The vessel of this reactor was at that time the longest in the world, and was designed and built by the company Combustion Engineering. In contrast, San Onofre had a 3-loop PWR and 365 MWe electrical output design (Figure 7c) [21,22]. That same year, 1968, the first nuclear power plant in Spain, José Cabrera, came into operation, which had a Westinghouse PWR with 150 MWe electrical output [23], becoming the only operational 1-loop PWR around the world (Figure 7a). Following these first plants, the North American company developed in 
parallel throughout the 1960s and 1970s the variants PWR 2-loop (Figure 7b), PWR 3-loop (Figure 7c), and PWR 4-loop (Figure 7d).

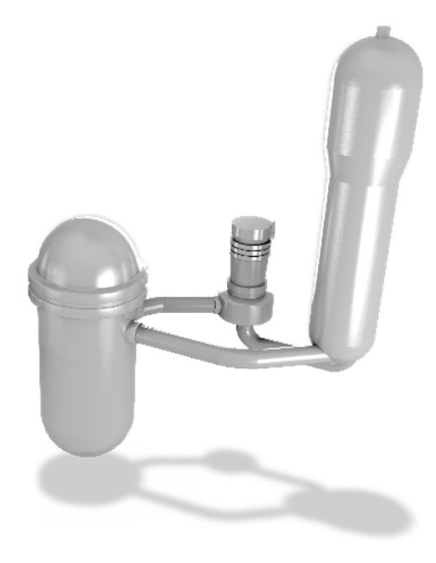

(a)

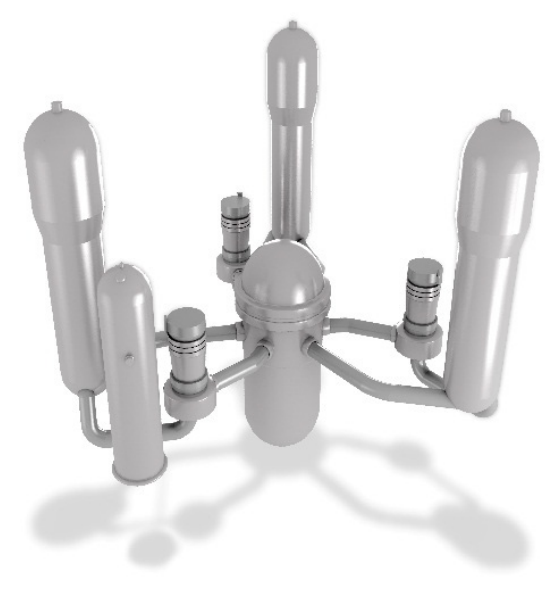

(c)

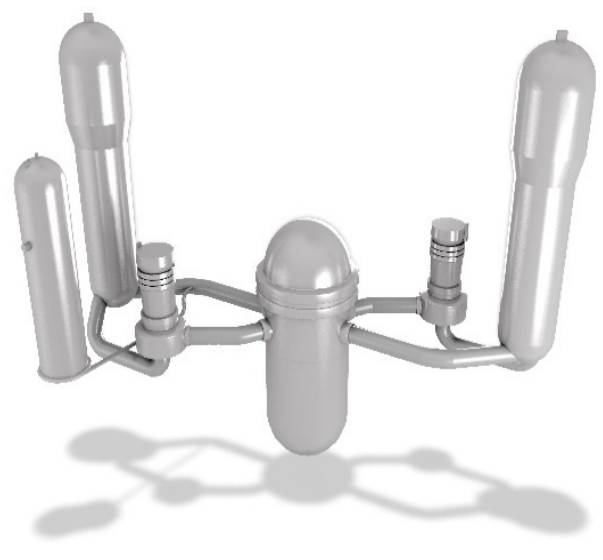

(b)

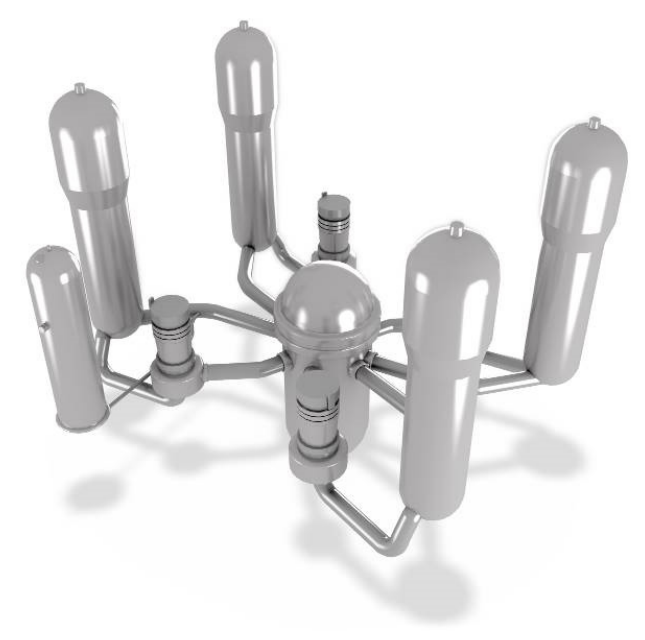

(d)

Figure 7. Westinghouse PWR designs: (a) 1-loop; (b) 2-loop; (c) 3-loop; and (d) 4-loop.

Starting in the 21st century, the US company has continued to bet on PWR design, developing Generation III design AP1000, 2-loop 1150 MWe PWR (Figure 7b) that uses the forces of nature and simplicity of design to enhance plant safety and operations and reduces construction costs [24,25]. AP1000 design continues to use prove components, and the inherent safety and simplicity of the AP600 design. The AP600 design was Westinghouse's initial start-up as Generation III PWR design, but predictions of a lack of competitiveness for this design prompted the company to develop the AP1000 [26].

\subsubsection{Babcock \& Wilcox PWR Design}

Throughout the 1970s and 1980s, 10 Babcock \& Wilcox (B\&W) PWR-designed nuclear power plants began commercial operation: Three Mile Island-1 and 2, Arkansas Nuclear One-1, David Besse-1, Oconee 1-2 and 3, Indian Point-1, Rancho Seco-1, and Cristal River-3. In the B\&W PWR design the primary circuit is based on 2-loops each formed by (i) a pipe from the vessel to the top of the steam generator, called the hot branch, and (ii) two lines that came from the lower part of the SG and connect to the vessel, called the cold branch of the primary circuit, in each of which a reactor coolant pump is installed (Figure 8). 
One of the most important differences between Babcock \& Wilcox PWR and other PWR designs is the steam generator. The B\&W PWR uses a type of steam generator called a once-through steam generator (OTSG), in which the heat transfer between the coolant-which enters through the top and descends inside a bundle of tubes-and the water from the supply, occurs in countercurrent, thereby generating steam at constant pressure in any power range. This difference supposes an operational advantage for other designs, since in a traditional steam-generator, i.e., U-tube steam generator (UTSG), the vapor pressure depends on the power $[27,28]$.

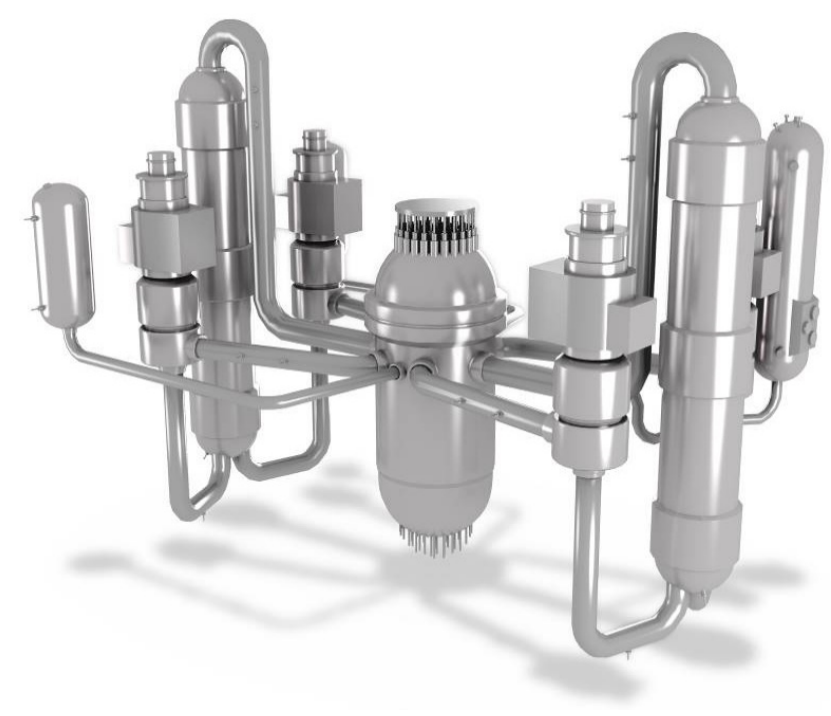

Figure 8. Babcock \& Wilcox PWR design.

\subsubsection{Combustion Engineering PWR Design}

Combustion Engineering (CE) built 15 nuclear power plants in the United States: Arkansas Nuclear One-2, Calvert Cliffs 1 and 2, Millstone-2, Palisades, Palo Verde 1-2 and 3, St. Lucie 1 and 2, and Waterford-3, Maine Yankee, San Onofre 2 and 3. This company's PWR design (called CE80) [10], is made up of 2-loops connected to the reactor vessel, located in the central part of the system. Unlike other variants, in each primary circuit there are two cold legs-connecting the steam generator outlet with the vessel一and in each of these legs a reactor coolant pump is installed (Figure 9). This first major modification of the traditional PWR design was due to the second fundamental modification in this variant, the increase in dimensions of the steam generator. This increase in the size of the steam generator results in an increase in the volume of the coolant, and therefore results in an improved design response to accident conditions with reduced inventory.

Another of the most characteristic modifications of the Combustion Engineering design (called CE80) was the $33 \%$ increase in the volume of the presser, which allowed for more efficient management in the case of Loss of Coolant Accident (LOCA). Likewise, this availability of a greater quantity of coolant in the pressurizer avoids the reactor trip during transients or load rejections. Unlike the rest of other PWR design variants, in the CE80 design the possible power variations during the design operation are only corrected with the control rods, so the need to adjust the boron concentration in the short term is reduced. 


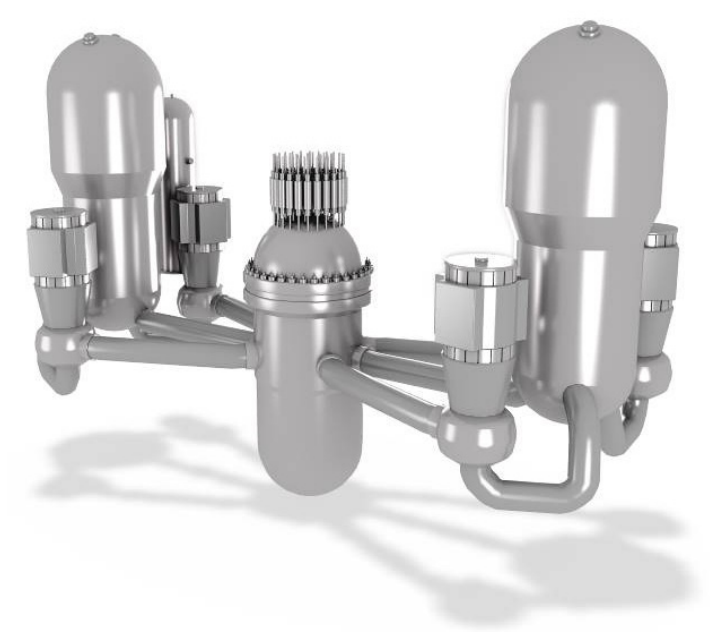

Figure 9. Combustion Engineering PWR design.

\subsection{French PWR Evolution}

France, one of the great world powers that developed nuclear energy as a source of electricity generation, opted in the initial phase of its nuclear program for gas-cooled reactors (GCR) and fast breeder reactors (FBR). However, in collaboration with Belgium, a PWR-designed nuclear reactor is being built at the Chooz-A nuclear power plant, very close to the border between the two countries [29]. Its construction began in 1961, and in 1967, the operation of the first commercial PWR nuclear reactor in Europe began.

In the 1970s, several series of the PWR design [30,31]—all of them 3-loop and 900 MWe electrical output-were developed in stages in France. These new series based on the PWR design were named $\mathrm{CP}$, CP1 and CP2. The CP0 series, fully under Westinghouse license, was only implemented during the 1970s, in the aforementioned Units 1 and 2 of Fessenheim and Units 2, 3, 4, and 5 of the Bugey nuclear power plant. Instead, the CP1 and CP2 series were implanted throughout the 1970s and 1980s, totaling 28 built nuclear reactors. These CPI and CP2 series benefited from the feedback obtained from the design, construction, and operation studies of the $\mathrm{CP} 0$ reactors. Unlike the design studies for the $\mathrm{CP} 0$ series, which were conducted separately for each site, the design studies for the $\mathrm{CP} 1$ and $\mathrm{CP} 2$ series were standardized. As a result, the $\mathrm{CP} 1$ and $\mathrm{CP} 2$ series differ from the $\mathrm{CP} 0$ series in (i) the design of the containment building-which was modified to facilitate operations inside, (ii) the location of the designed security systems-which were modified to increase the independence of the trains from the systems and increase their reliability, and (iii) more flexible reactor control—thanks to the use of control rods and the addition of control rods with less neutron absorption capacity.

Subsequently, it advanced to the plants of four primary circuits, which meant an increase in the generation capacity, reaching 1300 MWe. These new plants were called the P4 and $\mathrm{P}^{\prime} 4$ series. The initial design of the plants named P4 was based on a Westinghouse license, of which 8 units were built throughout the 1980s. However, in the face of such an ambitious and protectionist national nuclear program, the Framatome company developed its own "Frenchified" version of Westinghouse's P4 series, called $\mathrm{P}^{\prime} 4$, from which 12 units were built. The increase in power in these series $\mathrm{P} 4$ and $\mathrm{P}^{\prime} 4$ was achieved by increasing the size of the reactor. To eliminate the increase in thermal power for the initial series $\mathrm{CP} 0, \mathrm{CP} 1$ and $\mathrm{CP} 2$, it was necessary to install an additional loop (thus changing from 3-loop for the CP0, CP1 and CP2 reactors from 900 MWe to 4-loop for the series P4 and P'4 of $1300 \mathrm{MWe}$ ). The components of each loop-mainly Reactor Coolant Pump and Generator Steam-are also larger than those of the previous series. Regarding the location of the buildings, the new series are single-unit plants, while the previous series were double-unit plants.

The designed security systems and auxiliary systems are located in specific buildings of each unit to improve the safety of its operation. Additionally, each containment vessel has a double concrete wall 
(one pre-stressed concrete interior wall and one reinforced concrete exterior wall) in place of the single steel-lined pre-stressed concrete wall in the 900 MWe reactors. New microprocessor-based control and instrumentation technologies using programmable memory are used. The $\mathrm{P}^{\prime} 4$ series differs from the P4 series in that the installation of buildings and structures was optimized with the main objective of reducing costs. The result is a more complex plant design and smaller buildings and structures [32,33].

Finally, during the eighties, the Framatome company came to implement a French design for the PWR plant: the N4 design, four new plants were built with this N4 design: two new units in Chooz and another two units in Civeaux. With the help of advanced fuel and improvements to the main components of the secondary steam generation circuit, it offered a power of 1450 MWe with a 4-loop PWR. Currently, within Generation III, France continues to bet on the PWR design through the EPR (European Pressurized Reactor) design [34], with a generation capacity of 1600 MWe. The design of the Areva company - currently called Framatome-is based on the experience of the French N4 design and the Generation II German Konvoy design. Currently 2 EPR reactors are in operation in Taishan 1 and 2 (China) and meanwhile, the EPR Olkiluoto-3 (Finland) and Flamanville-3 (France) design nuclear power plants continue to be built. The United Kingdom is also betting on this design for the two units of the Hinkley Point nuclear power plant, that will be capable of generating $7 \%$ of the electrical energy consumed in the country from 2025 [35].

\subsection{Russian PWR Evolution}

In parallel with North American nuclear development, the former Soviet Union was also taking its first steps towards generating electric power from nuclear power. In 1954 the Soviet Union was able to start the operation of the world's first nuclear-powered nuclear reactor. It was the Obninsk nuclear power plant, based on the LWGR design, water-cooled, and moderated with graphite. This design, operational until 2002, had a generation capacity of 5 MWe. Soviet scientists and technicians went on to develop various designs of nuclear reactors with some success: LWGR, PWR and BWR. Finally, the communist regime opted for the development of the first two. As for the PWR design, the Soviet version was named Water-Water Energetic Reactor (WWER) [36,37], from the Russian Vodo-Vodyanoi Energetichesky Reaktor (VVER), which was developed by the company currently known as Rosatom. The main differences between the Soviet VVER design and the western PWR are [38]: (i) a hexagonal geometry of the fuel assemblies with the arrangement of the fuel rods in a triangular grid; (ii) the use of a zirconium-niobium alloy as a fuel rod clad material; (iii) the possibility of transporting all large equipment by rail, resulting in a limitation of the outside diameter of the reactor pressure vessel; and (iv) an original design of horizontal steam generators.

Within Generation I, the first two units of the NovoVoronezh nuclear power plant, named V-210 and V-365 based on their power generation capacity, served as prototypes of the VVER design. After the construction of these first two units, the construction of two units began at the NovoVoronezh nuclear power plant with the VVER-440 variant (Figure 10a). With minor changes from its predecessors, the VVER-440 design became the base design for the construction of more than twenty nuclear power plants around Europe: Slovakia, Hungary, the Czech Republic, Bulgaria, and Finland. The third stage of development of the VVER-440 design was the V-213 variant, which included as a design accident the severe breakage of the lines with the maximum diameter of the primary.

The continuous evolution of the VVER-440 design resulted in the VVER-1000 design (Figure 10b), first implemented in 1980 in Unit 5 of the NovoVoronezh nuclear power plant. While the VVER-440 reactor has six loops, the VVER-1000 design reduces the number of these to four [39]. This design was developed within Generation II and Generation III nuclear reactors (Figure 1). In this design, the reactor is located within a concrete containment. The number of fuel elements increased, and the number of control bars was reduced. 


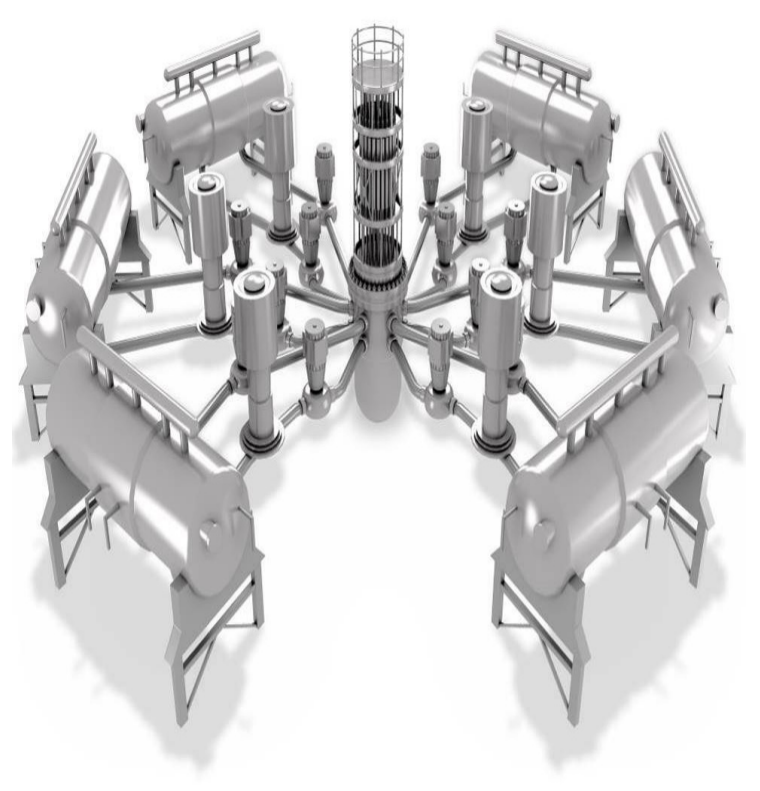

(a)

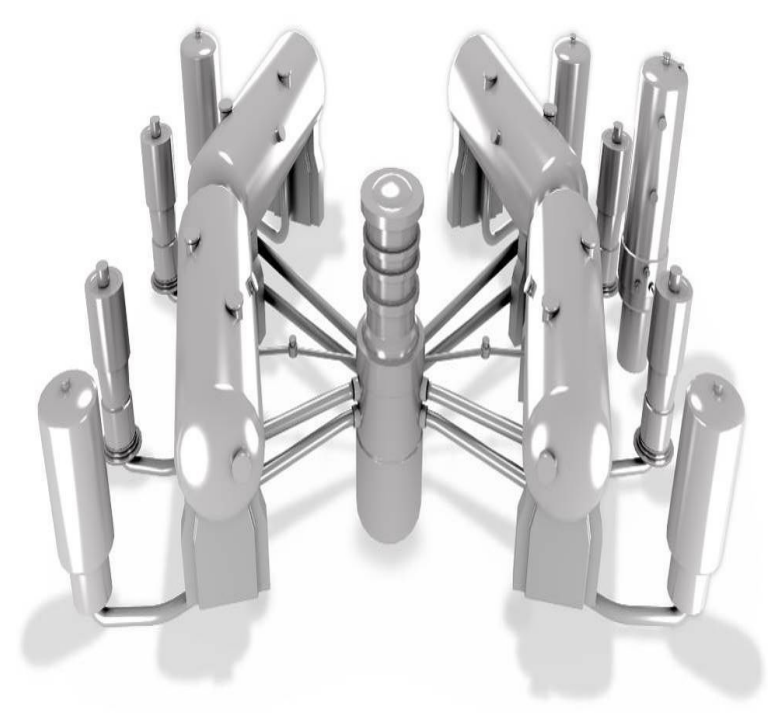

(b)

Figure 10. Rosatom VVER designs: (a) VVER-440; (b) VVER-1000.

In the mid-2000s, began the development of a yet further modernized design: the VVER-1200. The new Russian reactor Generation III+ VVER-1200 represents the latest model currently offered for construction by Rosatom. It is an evolutionary development of the well-proven VVER-1000 with an increasing thermal power to about $3200 \mathrm{MWt}$ and providing additional passive safety features [40].

\subsection{Chinese PWR Evolution}

The Chinese PWR nuclear reactor design program is based on the parallel development of three companies [41-43]: (i) China General Nuclear Power Corporation (CGN); (ii) China National Nuclear Corporation (CNNC); and (iii) State Nuclear Power Technology Corporation (SNPTC).

\subsubsection{China General Nuclear Power Corporation PWR Design}

The beginnings of the Chinese company CGN were based on French technology. The first 900 MWe units were exported by the Framatome company for the two units that were built at the Chinese Daya Bay and Ling-AO nuclear power plants respectively.

The design of these units ended up being called M310, which evolved in the following years to the CPR-1000 Generation II+ (Chinese PWR) design. The 3-loop CPR-1000 and 1086 MWe electrical output, has an operational cycle of 18 months. A major change from the original M310 design was the removal of the weld joint in the reactor pressure vessel, thus shortening component production time and eliminating the need to inspect the weld over the life of the reactor. The CPR-1000 has 157 fuel assemblies with $\mathrm{UO}_{2}$ enrichment of $4.5 \%$. The fuel assembly design is a $17 \times 17$.

The CPR-1000 has evolved to a more advanced variant, the Generation III ACPR1000 (advanced Chinese power reactor, based on PWR design). This design has several technical improvements such as: (i) greater generation capability; (ii) simplification of the chemical and volumetric control system; (iii) extension of its useful life; (iv) increased resistance to external events; (iv) greater length of fuel elements; (vi) increase in the heat transfer area of the steam generator; and (vii) increasing the capacity of the presser; and (viii) increased capability to withstand high concentrations of hydrogen thanks to the assembly of passive recombinants. 


\subsubsection{China National Nuclear Corporation PWR Design}

The CNNC company began the development of its line of CNP reactors (CNP nuclear power reactor) in the 1970s, during the research and development project of a nuclear reactor for use in submarines. The result was the PWR design named CNP-300, 1-loop PWR, and 300 MWe electrical output. The Generation II CNP-300 design evolved to Generation II CNP-600, 2-loop PWR, and 650 MWe electrical output. Later, the CNNC, together with the companies Westinghouse and Framatome, developed a Generation III PWR variant with three loops and a generation capacity of $1000 \mathrm{MWe}$, called CNP-1000. Later, the CNP-1000 design evolved to another Generation III design called ACP-1000 (advanced Chinese power reactor). Recently, both companies, CGN, and CNNC, joined forces to merge their respective PWR designs: the ACPR1000 and ACP-1000, in a design called HPR1000 (called Hualong one).

\subsubsection{State Nuclear Power Technology Corporation PWR Design}

Although the Westinghouse AP1000 Generation III design is the main foundation of the Chinese Generation III nuclear program, the State Nuclear Power Technology Corporation (SNPTC) has developed the Chinese version of this design, called CAP1400, one of the sixteen National Science and Technology Major Projects in China. The CAP1400 is an enlarged version of the AP1000, a 2-loop PWR, and a 1500 MWe electrical output reactor. This design is the largest Generation III PWR. Ensuring its advanced nature from the very beginning; CAP1400 comprehensively inherits the philosophy of the passive concept and the simplification of AP1000 [44-46].

\section{Discussion}

This section aims to compare the different variants of the PWR design throughout history. To achieve this, a study is carried out on different aspects: (i) analysis of the technical evolution of the different variants; (ii) the operating factor (OF) of PWR nuclear power plants; (iii) the under construction factor (UCF), which represents the relative frequency of reactors under construction around the world; and (iv) simulation of the electrical capability of both operational and under construction PWR nuclear power plants in a scenario of life extension of 60 years.

\subsection{Technical Aspect}

If we analyze the different relationships throughout the evolution of American, French, Russian, and Chinese PWR designs (Figure 11), we observe the existence of different technical influences throughout history, which have given rise to a large number of variety of designs with different related technical aspects. The beginnings of the PWR design are found in the different Westinghouse versions, in which both the number of loops and the size of the main components (reactor vessel, steam generator, reactor coolant pump and fuel assemblies) increased as new reactors were redesigned. These changes mainly favored an increase in electricity generation capacity. 


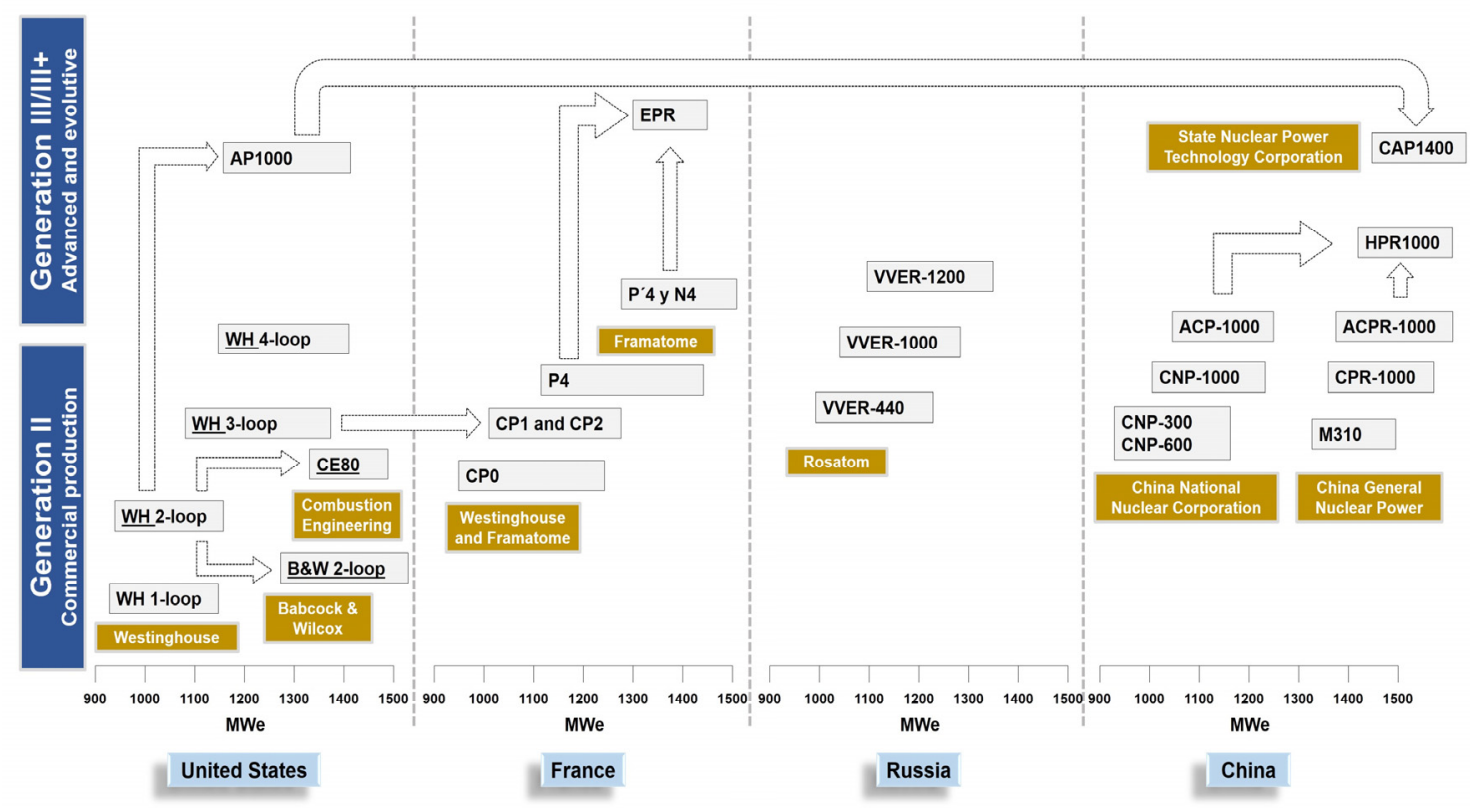

Figure 11. Evolution of PWR designs in the United States, France, Russia, and China.

As has already been shown, the 2-loop Westinghouse PWR was the reference for the development of two fundamental PWR designs in Generation II: Babcock \& Wilcox and Combustion Engineering CE80. Subsequently, CE80 was the reference model for the development of the Korean design OPR1000. However, these designs have as a fundamental difference the incorporation of a second cold branch in each of the loops. Therefore, this technical modification involved the second RCP. In the case of Babcock \& Wilcox, another fundamental modification of the original design was the addition of a once-through steam generator. All these modifications again meant an increase in power generation capacity.

Initially, Framatome opted for collaboration with Westinghouse to develop an entire nuclear industry around PWR design. Within Generation II, the French CP0 series features the 3-loop Westinghouse design, while the following $\mathrm{CP} 1$ and $\mathrm{CP} 2$ begin to include aspects typical of the French nuclear industry. These changes were further noted in the later P4 series-still in collaboration with Westinghouse- and on French $\mathrm{P}^{\prime} 4$ and N4-100\%. These new PWR series increase primary circuits and power generation capacity to 4 , but also expanded design safety, for example, increasing the redundancies of safety systems or improving the strength of the containment building.

In the case of the Russian VVER versions, it is more difficult to find similarities with other, Western PWR versions, since these designs have characteristics and differentiating aspects: (i) the hexagonal geometry of their fuel elements; (ii) the horizontal steam generators; and (iii) the increase in the number of loops. Lastly, the Chinese nuclear industry has been able to join this technological race, despite being 20 years behind. Initially, it opted for collaboration with the great western powers to develop the first PWR Generation II designs, but nowadays it has been able to generate enough autonomy to develop its designs. To know more about this topic, the main parameters of the final Generation II designs are described in Table 2. 
Table 2. Main parameters of United States, France, Russia, and China final PWR Generation II designs.

\begin{tabular}{cccccc}
\hline Design & $\begin{array}{c}\mathbf{n}^{\mathbf{0}} \text { loop/ Steam } \\
\text { Generators }\end{array}$ & Fuel Assemblies & $\begin{array}{c}\text { Trains Emergency } \\
\text { Core Cooling System }\end{array}$ & $\begin{array}{c}\text { Thermal } \\
\text { Capacity (MWt) }\end{array}$ & $\begin{array}{c}\text { Electrical } \\
\text { Output (MWe) }\end{array}$ \\
\hline WH 4-loop & 4 & 193 & 2 & 3400 & 1200 \\
B\&W 2-loop & 2 (OTSG) & 205 & 2 & $2600-2800$ & 900 \\
CE80 & 2 & 241 & 2 & $2600-2800$ & 900 \\
N4 & 4 & 205 & 2 & 4250 & 1450 \\
VVER-1000 & 4 (horizontal) & 163 & 4 & 3000 & 1000 \\
ACP-1000 & 3 & 177 & 3 & 3060 & 1100 \\
ACPR-1000 & 3 & 177 & 3 & 3500 & 1150 \\
\hline
\end{tabular}

In Generation III, the differences between the current PWR designs are maintained, although it is possible to establish certain relationships between the reference designs: AP1000, EPR, VVER-1200, HPR1000, and CAP1400 [46,47]. Thus, according to the data collected from [15,46,48], the main parameters of these designs are described in Table 3. Furthermore, in these PWR Generation III the core damage frequency considering the contribution from internal and external events is less than $10^{-5}$ events per reactor-year.

Westinghouse continues its commitment to the inherent safety-or passive safety-and the modular construction and simplicity of the AP1000 design. This AP1000 design is the reference for the Chinese PWR Generation III design, the CAP1400. The CAP1400 maintains the AP1000 design philosophy, increasing electrical generating capacity. Both designs, AP1000 and CAP1400 have a core-catcher; if there was a core meltdown, the core would be "caught" and prevented from entering the environment. In the case of the Russian VVER-1200, this design has technical aspects similar to the French EPR, e.g., 4 independent trains of emergency safeguards and double containment building. They are designs that bet on the increase in the number of trains in the safety systems, as well as their redundancies, moving away from the passive safety of the previous AP1000 and CAP1000 designs.

Table 3. Main parameters for United States, France, Russia, and China PWR Generation III designs.

\begin{tabular}{cccccccc}
\hline Design & $\begin{array}{c}\mathbf{n}^{\mathbf{0}} \text { loop/ Steam } \\
\text { Generators }\end{array}$ & Passive Safety & Core-catcher & $\begin{array}{c}\text { Modular } \\
\text { Construction }\end{array}$ & Efficiency & $\begin{array}{c}\text { Electrical } \\
\text { Output (MWe) }\end{array}$ & $\begin{array}{c}\text { Core Damage } \\
\text { Frequency (Events } \\
\text { Reactor-Year) }\end{array}$ \\
\hline AP1000 & 2 & Yes & No & Yes & $32 \%$ & 1150 & $<5 \times 10^{-7}$ \\
EPR & 4 & Minimal & Yes & No & $36 \%$ & 1650 & $<10^{-5}$ \\
VVER-1200 & 4 (horizontal) & Minimal & Yes & No & $33.9 \%$ & 1200 & $<7.37 \times 10^{-6}$ \\
HPR1000 & 3 & Minimal & No & No & $36.6 \%$ & 1150 & $<10^{-6}$ \\
CAP1400 & 2 & Yes & No & Yes & $34.5 \%$ & 1500 & $<10^{-5}$ \\
\hline
\end{tabular}

Finally, the Chinese versions: ACPR-1000, ACP-1000, and HPR1000 maintain the number of loops of the first Generation II designs and the first French series. In these cases, the modular construction of the plant is not possible, and unlike the CAP1400, the ACPR-1000, and ACP-1000 designs do not have passive safety systems.

\subsection{Operating PWR Nuclear Power Plants}

Taking as a reference the 300 PWR nuclear reactors operating around the world in early 2020 [6], it is observed that the countries where this design has been mostly implemented are the United States, France, China, and Russia (Table 4). Besides, these countries are also the ones with the most operational nuclear reactors in their territory. According to Table 4, the PWR design is fully implemented in the cases of France and China. However, in the United States and Russia, there is greater diversification of technologies, since the PWR design accounts for approximately $60 \%$ of the operating nuclear reactors. This may be because in France and China they adapted nuclear technology later than in the United States or Russia, and consequently learned from the experience of predecessor countries in choosing their reactor design. Other countries outside the scope of this global PWR review, but with a high number of operating reactors in their territory, are Korea and Japan. On one hand, among the 
24 operating reactors in Korea, 21 have PWR technology. On the other hand, Japan has a total of 33 operating reactors, and among them, 16 are PWR.

Table 4. PWR designs in United States, France, Russia, and China.

\begin{tabular}{cccc}
\hline Country & Number of PWR & Number of Reactors & \% PWR \\
\hline USA & 64 & 96 & $67 \%$ \\
FRANCE & 58 & 58 & $100 \%$ \\
CHINA & 45 & 48 & $94 \%$ \\
RUSSIA & 23 & 38 & $61 \%$ \\
\hline
\end{tabular}

Table 5 analyzes various data from the PWR designs developed in the United States, France, Russia, and China, specifically: (i) Generation, (ii) Electrical output range; (iii) number of reactors; and (iv) the parameter OF.

To carry out the analysis comparing companies or countries, a new parameter is necessary. Thus, the global operating factor (GOF) is defined as the sum of the OF for a specific set of designs grouped: (i) by country, (ii) by design, or (iii) by company. Among the PWR designs are those developed by the American company Westinghouse: WH 2-loop, WH 3-loop, and WH 4-loop, as well as the different series of the French PWR design: CP1, CP2, N4 and P4 and the Russian variant VVER-1000, already in Generation II+. Thus, Table 5 shows that the VVER-1000 design is the most implemented around the world, with 37 operating units ( $\mathrm{OF}=12.33 \%)$. However, the different variants of the American Westinghouse are the most implanted around the world, with GOF upper than $25 \%$.

In a second group would be the variants developed by the American companies Combustion Engineering and Babcock \& Wilcox. These two variants of the PWR design achieve a GOF of 5\%, assuming a GOF for American suppliers of the PWR design of over 30\%. Lastly, regarding the Western versions, the first units of the Westinghouse AP1000 designs and Framatome EPR, within Generation III, as well as the Russian floating nuclear power plants KLT-40 [49,50], have started operations. As for the Chinese variants of the PWR design, the CNP-300 and CNP-600 designs stand out. Within this group of oriental variants, the 23 units of the Chinese CPR-1000 design already appear, within that of Generation II+ [51].

Taking into account the expansion mechanism, that is, how PWR design has been implemented in other countries, the result is different from that obtained by analyzing the number of operational reactors. In the case of the United States, Westinghouse maintains its operational designs in 9 different countries (Figure 12): (i) PWR 2-loop: 6 reactors operating in Switzerland, Belgium, Slovenia, and Brazil; (ii) PWR 3-loop: 18 reactors operating in Korea, Spain, Belgium, Taiwan, and Sweden; (iii) PWR 4-loop: 1 reactor operating in the United Kingdom. In the United States, the Westinghouse company maintains 48 PWR reactors (GOF $=34 \%$ ), distributed as follows: (i) PWR 2-loops: 5 reactors, (ii) PWR 3-loop: 13 reactors; and (iii) PWR 4-loop: 30 reactors.

Table 5. PWR designs operating in the United States, France, Russia, and China.

\begin{tabular}{ccccc}
\hline Design/Overvall & Generation & $\begin{array}{c}\text { Electrical Output } \\
\text { Range (MWe) }\end{array}$ & Number of Reactors $(\boldsymbol{n})$ & Operating Factor (\%) \\
\hline UNITED STATES & & & & 0.00 \\
\hline Westinghouse & Generation II & 150 & 0 & 3.67 \\
WH 1-loop & Generation II & $500-900$ & 11 & 10.33 \\
WH 2-loop & Generation II & $800-950$ & 31 & 10.33 \\
WH 3-loop & Generation II & $800-1180$ & 31 & 1.33 \\
WH 4-loop & Generation III & 1150 & 4 & 1.67 \\
AP1000 & Generation II & $825-1000$ & 5 & 3.67 \\
Babcock \& Wilcox & Generation II & $850-1200$ & 11 & \\
B \&W & & & & \\
CEmbustion Engineering & & &
\end{tabular}


Table 5. Cont.

\begin{tabular}{|c|c|c|c|c|}
\hline Design/Overvall & Generation & $\begin{array}{l}\text { Electrical Output } \\
\text { Range (MWe) }\end{array}$ & Number of Reactors $(n)$ & Operating Factor $(\%)$ \\
\hline \multicolumn{5}{|l|}{ FRANCE } \\
\hline \multicolumn{5}{|l|}{$\overline{\text { Framatome }}$} \\
\hline CP0 & Generation II & 900 & 7 & 2.33 \\
\hline CP1 & Generation II & 900 & 22 & 7.33 \\
\hline $\mathrm{CP} 2$ & Generation II & 900 & 10 & 3.33 \\
\hline P4 & Generation II & 1300 & 20 & 6.67 \\
\hline N4 & Generation II & 1500 & 4 & 1.33 \\
\hline EPR & Generation III & 1650 & 2 & 0.67 \\
\hline \multicolumn{5}{|l|}{$\underline{\text { RUSSIA }}$} \\
\hline \multicolumn{5}{|l|}{$\overline{\text { Rosatom }}$} \\
\hline VVER-440 & Generation II & 440 & 22 & 7.33 \\
\hline VVER-1000 & Generation II+ & 1000 & 37 & 12.33 \\
\hline VVER-1200 & Generation III+ & 1200 & 3 & 1.00 \\
\hline \multicolumn{5}{|c|}{ CHINA } \\
\hline \multicolumn{5}{|c|}{ China $\overline{\text { General Nuclear }}$} \\
\hline M-310 & Generation II & 900 & 4 & 1.33 \\
\hline CPR-1000 & Generation II+ & 1080 & 23 & 7.67 \\
\hline ACPR-1000 & Generation III & 1150 & 1 & 0.33 \\
\hline \multicolumn{5}{|c|}{ China National Nuclear } \\
\hline \multicolumn{5}{|c|}{ Corporation } \\
\hline CNP-300 & Generation II & 300 & 5 & 1.67 \\
\hline CNP-600 & Generation II & 600 & 6 & 2.00 \\
\hline
\end{tabular}

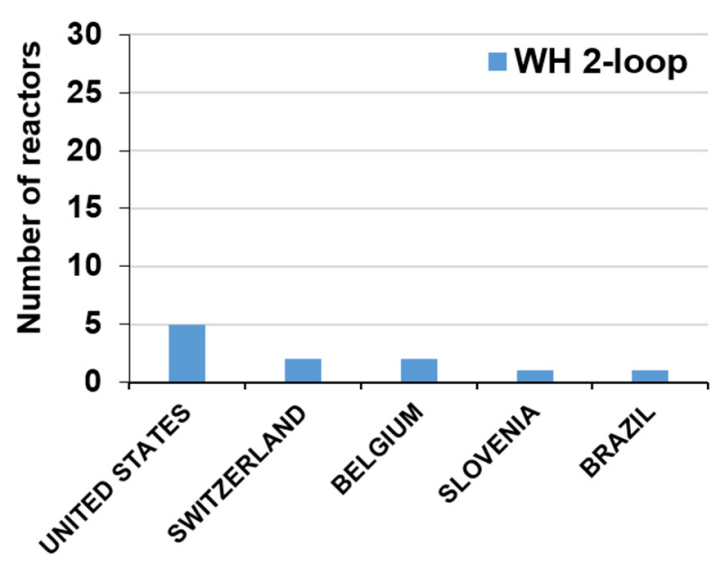

(a)

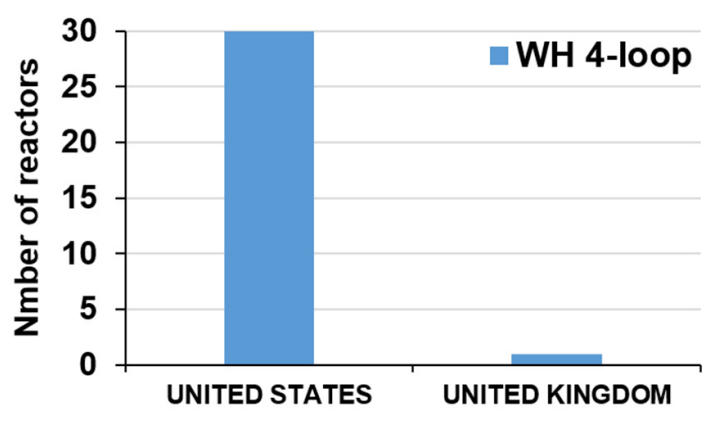

(c)

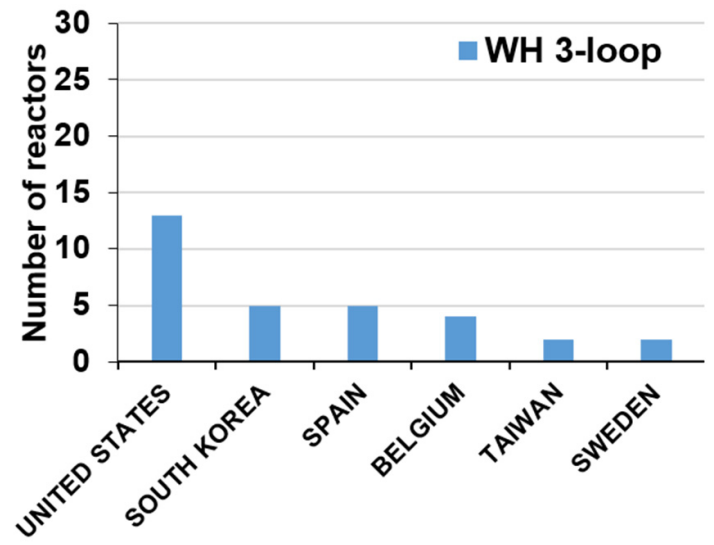

(b)

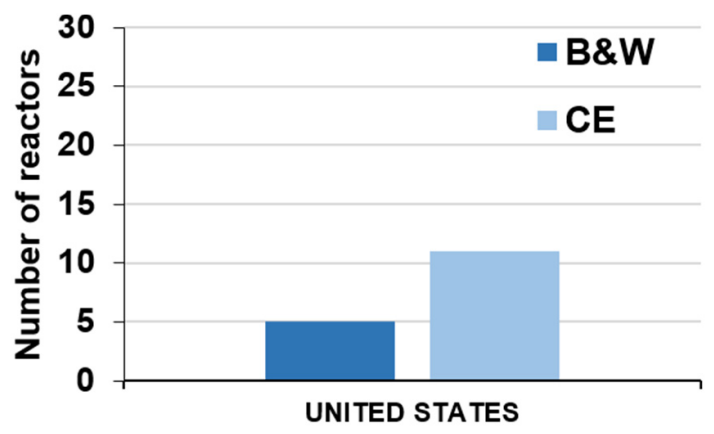

(d)

Figure 12. US PWRs operating worldwide: (a) WH 2-loop; (b) WH 3-loop; (c) WH 4-loop; (d) B\&W and CE.

On the other hand, there would be four AP-1000 Generation III reactors operating in China. In the case of Babcock \& Wilcox and Combustion Engineering, 100\% of its operating reactors are located in the United States, with 5 and 11 PWR Generation II reactors operating, respectively. 
In the case of France, the different variants of the PWR design developed throughout the past 20th century have had an expansion mechanism based on satisfying the demand of their national industry. Of the 58 nuclear reactors operating in France, 100\% have a PWR design; however, several CP1 3-loop units supplied by Framatome continue to operate worldwide (Figure 13): two units in South Africa and another two units in Korea. The other variants: CP2 3-loop, P4 4-loop, and N4 4-loop have not been implemented outside of French territory. On the other hand, within Generation III there has been an export of the technology, and there are already two operating EPR reactors in China.

In the case of the Russian VVER designs, the expansion mechanism is different from that developed by the North American and French designs, since of the 22 VVER-440 reactors operating around the world, 77\% have been implanted outside the country (Figure 14a): Slovakia, the Czech Republic, Hungary, Ukraine, Finland, Armenia. In the case of the Generation II + VEER-1000 design, the previous trend is maintained-specifically, $65 \%$ of these reactors remain operational outside their country of origin: Ukraine, China, India, the Czech Republic, Bulgaria and Iran (Figure 14b). In the case of Generation III and Generation III + of safe nuclear reactor designs, the Russian commitment to the VVER-1200 design is already operational at three national sites.

Finally, in the case of China, after years of expansion of nuclear technology in its territory, and especially of PWR design, there has been no international expansion. Its expansion mechanism bears certain similarities with the French case in the 1970s and 1980s. China encompasses 34 national Generation II and Generation II + PWR nuclear reactors (Figure 15): (i) 4 units M-310; (ii) 23 CPR-1000 units; (iii) 6 CNP-600 units, and (iv) 1 CNP-300 unit. These units should be added to the four CNP-300 reactors operating in Pakistan and the ACPR-1000 Generation III reactor operating in China.

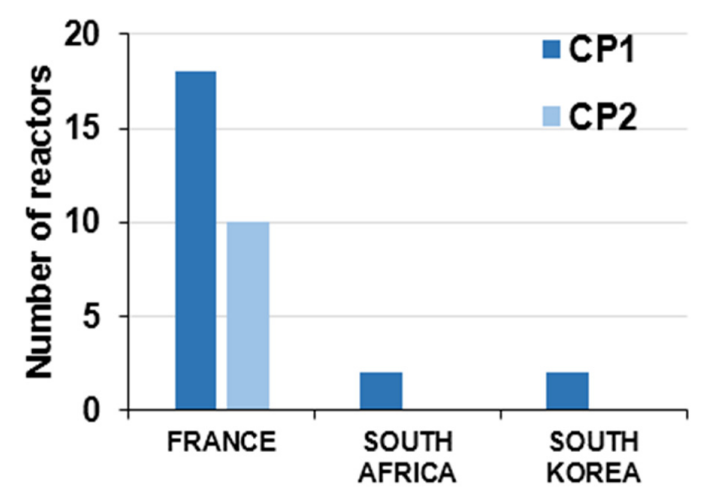

(a)

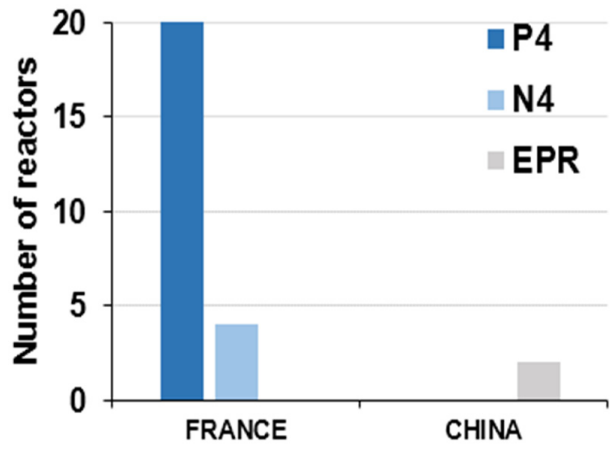

(b)

Figure 13. French PWRs operating worldwide: (a) CP1 and CP2; (b) P4, N4 and EPR.

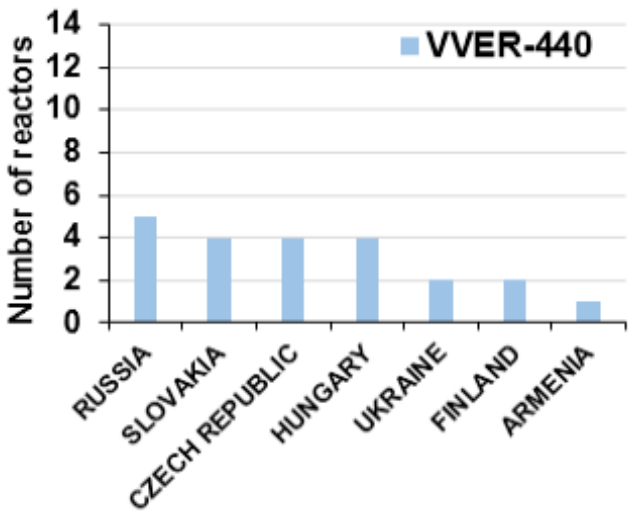

(a)

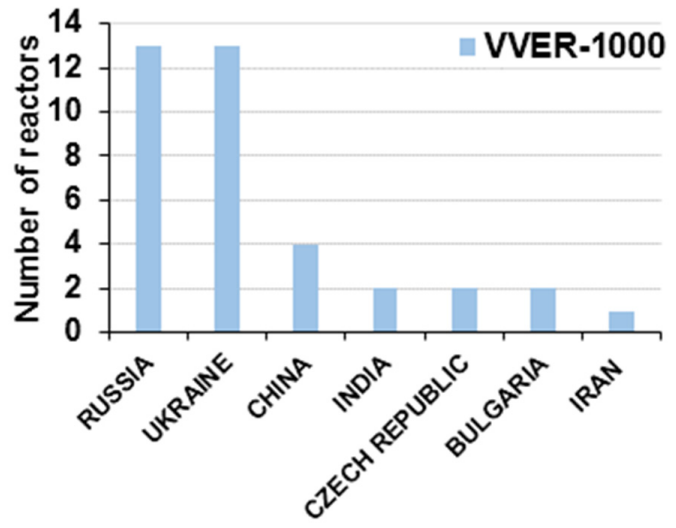

(b)

Figure 14. Russian PWRs operating worldwide: (a) VVER-440; (b) VVER-1000. 


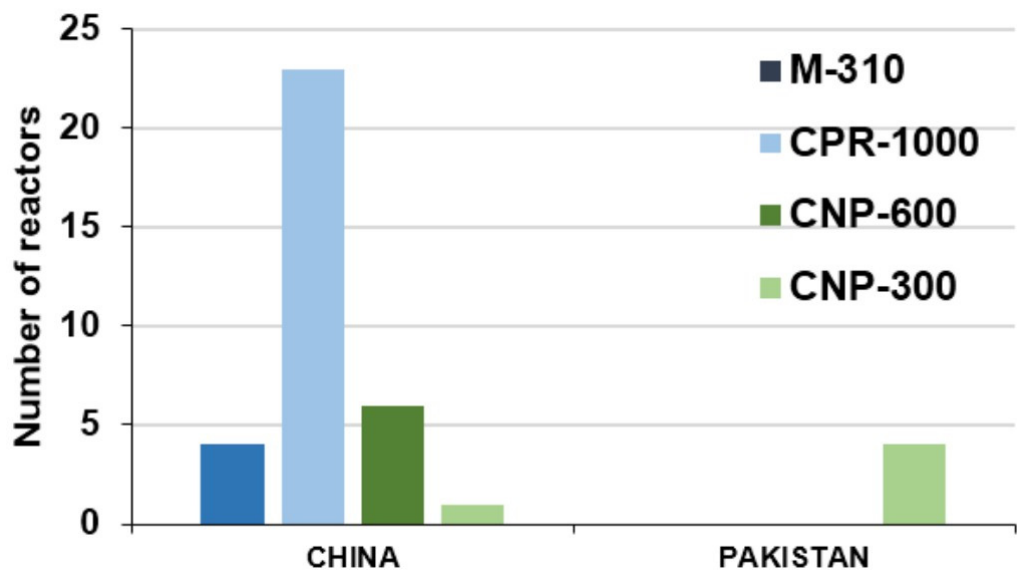

Figure 15. Chinese PWR (CGN and CNNC) operating in the world.

\subsection{Under Construction PWR Nuclear Power Plants}

After studying the current situation of the PWR design, it is convenient to analyze the international expansion plans of these four nuclear powers, studying different aspects of the future forecast of the PWR design: (i) Generation, (ii) Electrical output range; (iii) number of reactors; (iv) the parameter UCF (Table 6). To carry out the analysis comparing companies or countries, a new parameter is necessary. Thus, the global under construction factor (GUCF) is defined as the sum of the UCF for a specific set of designs grouped: (i) by country, (ii) by design or (iii) by company. Based on the GUCF parameter, of the 52 nuclear reactors currently under construction, 42 will have a PWR design, representing a GUCF of $80 \%$. In the case of the countries where the PWR design has been implemented the most (United States, France, Russia and China), the GUCF is $63 \%$. The only PWR construction projects with designs different from those of the four powers are: (i) APR-1400: four units in the United Arab Emirates and four units in Korea (country of origin of the design); and (ii) Konvoi: one unit in Brazil. Thus, the APR-1400 is, along with EPR, HPR1000 and VVER-1200, the most ambitious Generation III PWR design under construction.

Table 6. United States, France, Russia, and China PWR designs under construction.

\begin{tabular}{|c|c|c|c|c|}
\hline Design/Overvall & Generation & $\begin{array}{l}\text { Electrical Output } \\
\text { (MWe) }\end{array}$ & $\begin{array}{l}\text { Number of } \\
\text { Reactors }(n)\end{array}$ & $\begin{array}{c}\text { Under Construction } \\
\text { Factor }(\%)\end{array}$ \\
\hline \multicolumn{5}{|l|}{ UNITED STATES } \\
\hline $\begin{array}{l}\text { Westinghouse } \\
\text { AP1000 }\end{array}$ & Generation III & 1150 & 2 & 3.84 \\
\hline \multicolumn{5}{|l|}{ FRANCE } \\
\hline $\begin{array}{c}\text { Framatome } \\
\text { EPR }\end{array}$ & Generation III & 1650 & 4 & 7.69 \\
\hline CHINA & & & & \\
\hline $\begin{array}{c}\text { China General } \\
\text { Nuclear Power } \\
\text { ACPR-1000 } \\
\text { China National } \\
\text { Nuclear }\end{array}$ & Generation III & 1150 & 2 & 3.84 \\
\hline $\begin{array}{c}\text { Corporation } \\
\text { CNP-1000 } \\
\text { ACP-1000 } \\
\text { HPR1000 }\end{array}$ & $\begin{array}{l}\text { Generation III } \\
\text { Generation III } \\
\text { Generation III }\end{array}$ & $\begin{array}{l}1000 \\
1000 \\
1150\end{array}$ & $\begin{array}{l}2 \\
2 \\
5\end{array}$ & $\begin{array}{l}3.84 \\
3.84 \\
9.61\end{array}$ \\
\hline$\underline{\text { RUSSIA }}$ & & & & \\
\hline $\begin{array}{c}\text { Rosatom } \\
\text { VVER-1000 } \\
\text { VVER-1200 }\end{array}$ & $\begin{array}{c}\text { Generation II+ } \\
\text { Generation III+ }\end{array}$ & $\begin{array}{l}1000 \\
1200\end{array}$ & $\begin{array}{l}7 \\
9\end{array}$ & $\begin{array}{l}13.46 \\
17.30\end{array}$ \\
\hline
\end{tabular}


As previously seen in the evolution graph of the different PWR designs (Figure 11), the design evolves within Generation II+ and Generation III+ as a safer and more efficient design, developed in different variants: (i) AP1000; (ii) EPR; (iii) HPR1000 [52]; and (iv) VVER-1000 and VVER-1200. Based on the results obtained analyzing the situation of the PWR reactors under construction (Table 6), it can be affirmed that the Russian variants are those that have UCF $13.46 \%$ in the case of the VVER-1000, and $17.30 \%$ in the case of the VVER-1200. This makes GUCF higher than $30 \%$. Therefore, they maintain their international expansion mechanism, without neglecting the need to cover the internal demand for nuclear reactors.

In the case of the North American and French Generation III PWR designs, AP1000 and EPR, they have lost the relevant role that their predecessor designs (Figure 11) had during the 20th century, obtaining GUCF of $3.84 \%$ and $7.69 \%$, respectively.

Finally, it is the different Chinese PWR design variants that undergo a fundamental change in their expansion mechanism. These variants go from having a GOF of over $10 \%$ in operational PWR reactors around the world today to having a GUCF of over $21 \%$ in operating nuclear reactors in the near future. The GUCF of the Russian and Chinese PWR designs under construction is close to $50 \%$. Therefore, unlike what happened with PWR reactors in operation, 50\% of PWR reactors under construction are of Asian origin.

Analyzing the expansion mechanism of the different PWR designs under construction around the world, a protectionist expansion mechanism is observed in Europe and the United States. Of the 42 PWRs under construction around the world, 12 are being built in Europe and the United States, accounting for $28 \%$ of the total. In the case of Europe, countries such as France, Finland, and the United Kingdom are committed to EPR design as nuclear generation technology, while, in the United States, the technology under construction is its own Generation III AP1000 design. On the other hand, in the case of the former countries of the Soviet Union: Belarus, Slovakia, and Ukraine, a technological dependence is shown towards the different Russian VVER versions (Figure 16).

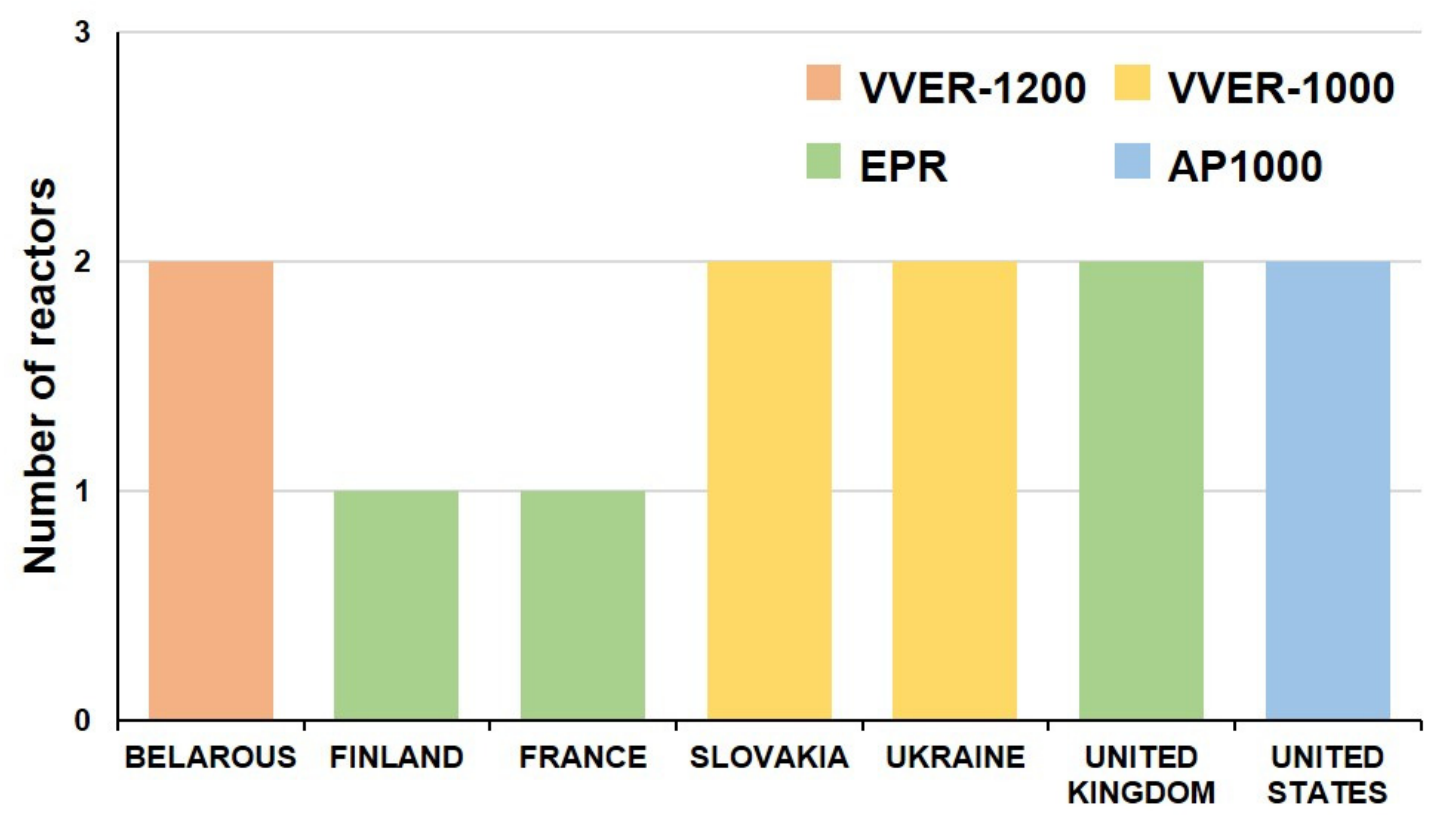

Figure 16. Number of PWR nuclear reactors under construction in Europe and United States.

In the case of construction PWRs in Asia (Figure 17), what is reflected in the GUCF study is maintained, where the Asian variants are the most widely implemented around the world, highlighting the implementation of the VVER-1000 and VVER-1200 designs. Regarding the expansion mechanism, $63 \%$ of the rectors under construction have Russian and Chinese PWR version. Russia, in addition to satisfying the national demand for nuclear reactors, exports its designs to countries such as Bangladesh, 
India, Iran, and Turkey. Like Russian designs, Chinese designs supply domestic demand with nine PWRs under construction (five HPR1000 reactors, two ACPR-1000 units, and two ACP-1000 units).

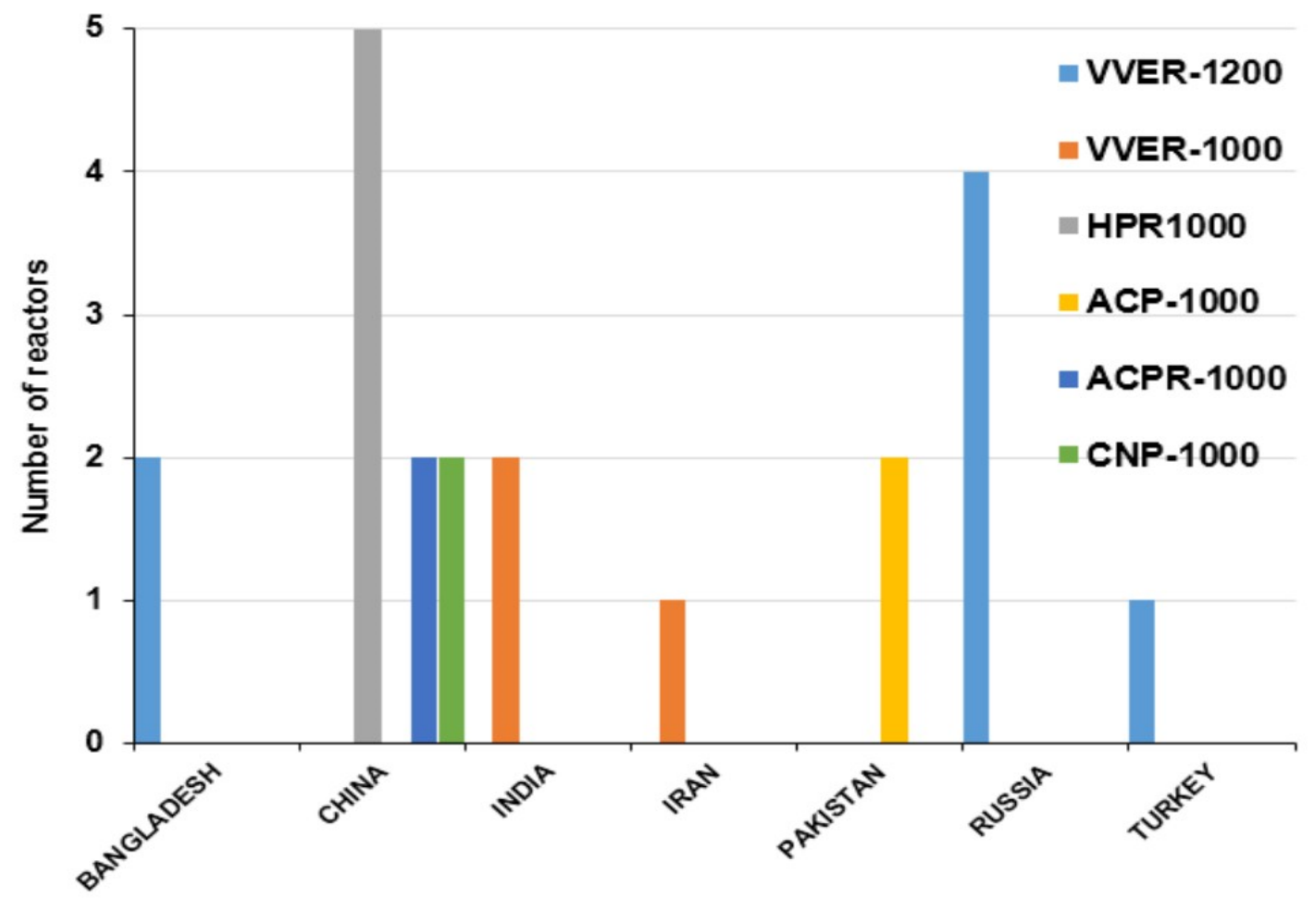

Figure 17. Number of PWR nuclear reactors under construction in Asia.

Bearing in mind that other Asian PWR designs such as the Korean APR-1400 or the Japanese APWR [48] should be added to this result, the trend reflected by the GUCF regarding the expansion of Asian versions of the PWR design is confirmed. The reason for not including these designs in the scope of this article is that they have a lower level of number of operational reactors than the great world powers. The great world powers that have promoted PWR design throughout the past 20th century, France and the United States, have given up their advantageous position in favor of the new Asian powers, China and Russia. This result confirms that the nuclear industry in Asia is in an advanced evolutionary stage, which is in agreement with previous studies [53].

Similarly to Figure 4, a new data group was collected from SCOPUS (Figure 18) with the number of articles that include the name of Generation III designs (AP1000, EPR, VVER-1200, HPR1000 and CAP1400) in the title, abstract or keyword. According to Figure 18, the total number of 971 papers in the SCOPUS database includes the denomination of the most important Generation III designs. Among this criterion, 646 of the total published papers (around 66\%) include "AP1000", so this design gets the highest number of papers among the Generation III designs. Secondly, 225 of the published research papers (around 23\%) are linked with "EPR". The rest of the Generation III designs consulted ("VVER-1200", "HPR1000" and "CAP1400") only add up to 100 of the published research papers (around 11\%).

As shown in Figure 18, scientific interest in the AP1000 design increased markedly from 2011. This sudden interest in this design may have resulted from the accident at the Fukushima-Daiichi Japanese nuclear power plant, which occurred on 11 March 2011. Although all four units of this nuclear power plant had BWR reactors, the evolution and consequences of the accident may have influenced the increased scientific interest in the design and safety criteria of the AP1000 design. Similarly, in 2017 the scientific interest in PWR design suffered a decrease of approximately 20\% (all the PWR designs exhibit a decrease in scientific production, as shown in Figure 18). This decrease could be a consequence of the financial crisis that the Westinghouse Company suffered in 2017. 


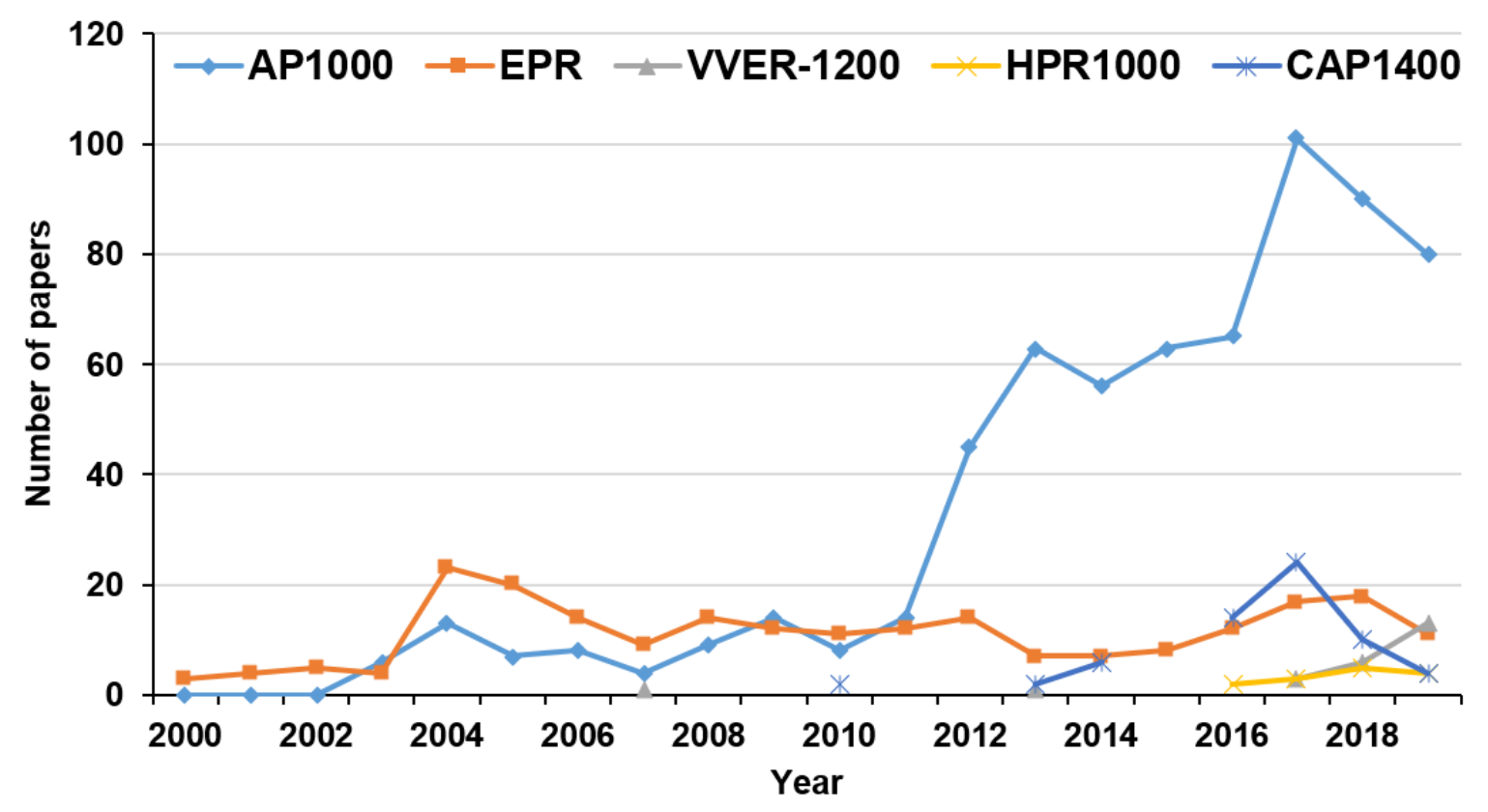

Figure 18. Number of research papers indexed in SCOPUS related with the Generation III designs (data collected on April 2020).

\subsection{Simulation of the Life Extension of Operational PWR}

The extension of the operating life of nuclear power plants is a solution to energy production-without carbon emissions-for a long time [54]. Due to the aging in the most important components-which implies a continuing time-dependent degradation of materials due to service conditions, including normal operation and transient conditions- the nuclear power plants are initially designed for a technical life of 40 years [55]. It is common experience that over long periods, there is a gradual damage in the properties of materials as a consequence of neutron radiation and the corrosion these components endure [56-58]. Thus, the reactor vessel materials of the PWR design are the components most affected by neutron radiation, thereby reducing its mechanical properties [59]. On the other hand, the SG is the component of PWR design suffering the most corrosion damage [28,60], being both stress corrosion cracking (SCC) and particle deposition the main degradation mechanisms. The degradation of steam generators tubes has involved costly modifications, inspections and even the replacement of SG in the most severe cases [61,62].

Although the technical life of 40 years is recommended in previous studies [56], other papers [63] consider that the 40-year term was based on economic and antitrust considerations rather than on technical limitations. In recent years, countries such as France or the United States have studied the lifetime extension significantly beyond 40 years: specifically, a lifetime extension up to 60 years [64]. The PWR Generation III designs were designed for a life of 60 years [65,66], and the United States is even planning a lifetime extension up to 80 years [67-71].

According to the IAEA, the half-life of operating nuclear reactors around the world is currently over 30 years [72] and in cases such as WH 2-loop, B\&W, and CP0 (Generation II), the designs have already reached the initial life of 40 years [6]. In this situation, in order to provide information for making a decision about the life extension beyond the initial 40 years, this study presents a simulation of the electrical power generation capacity of operational PWR in a scenario of lifetime extension to 60 years, consequently placing a maximum time horizon in the year 2050. To do this, the progressive implementation of the PWRs that is currently under construction is also taken into account, estimating for this a construction and commissioning time of 68 months (approximately 6 years), according to previous studies [72]. 
The results shown in Figure 19, in a scenario of lengthening the useful life of PWR nuclear power plants to 60 years, are clear: (i) the B\&W and French series CP0 will shut down in 2040 and (ii) Westinghouse 2-loop and 3-loop, Combustion Engineering CE80 and French series CP1 and CP2 will shut down in 2050. In this way, the PWR design would go from having 259 operating in 2020 in the world to 81 nuclear reactors operative in 2050, which means $69 \%$ less operating reactors in 30 years (Figure 19). In addition, 178 PWR nuclear power plants would permanent shutdown in 30 years.

Even considering new PWR nuclear power plants that could be projected in the coming years, this technology will suffer a drastic reduction in the coming years. The possible increase in the useful life to 60 years of the current operational PWRs would mean that this design maintains its global impact for other designs during the period 2020-2030, in which only 24 reactors would go into shutdown and the power generation capacity would increase as new Generation III designs-with higher generating capacity - now under construction start operating. According to Figure 19, starting in 2040, the PWR nuclear power plants will notably reduce their electrical capacity. This situation is likely to influence decisions about future investment and operating costs [71], as well as prospects for the decommissioning and management of high-level radioactive waste at current nuclear power plants [72-77]. Lastly, if no advances are made in R\&D of new designs or in the use of the actual nuclear power plants in cogeneration systems for the production of hydrogen [78,79], in 2050 this technology will decrease its generation capacity to 50\%, keeping 127 GWe and the number of operating rectors at $70 \%$. It is worth noting that these data are underestimated and, hence, this situation will likely occur earlier.

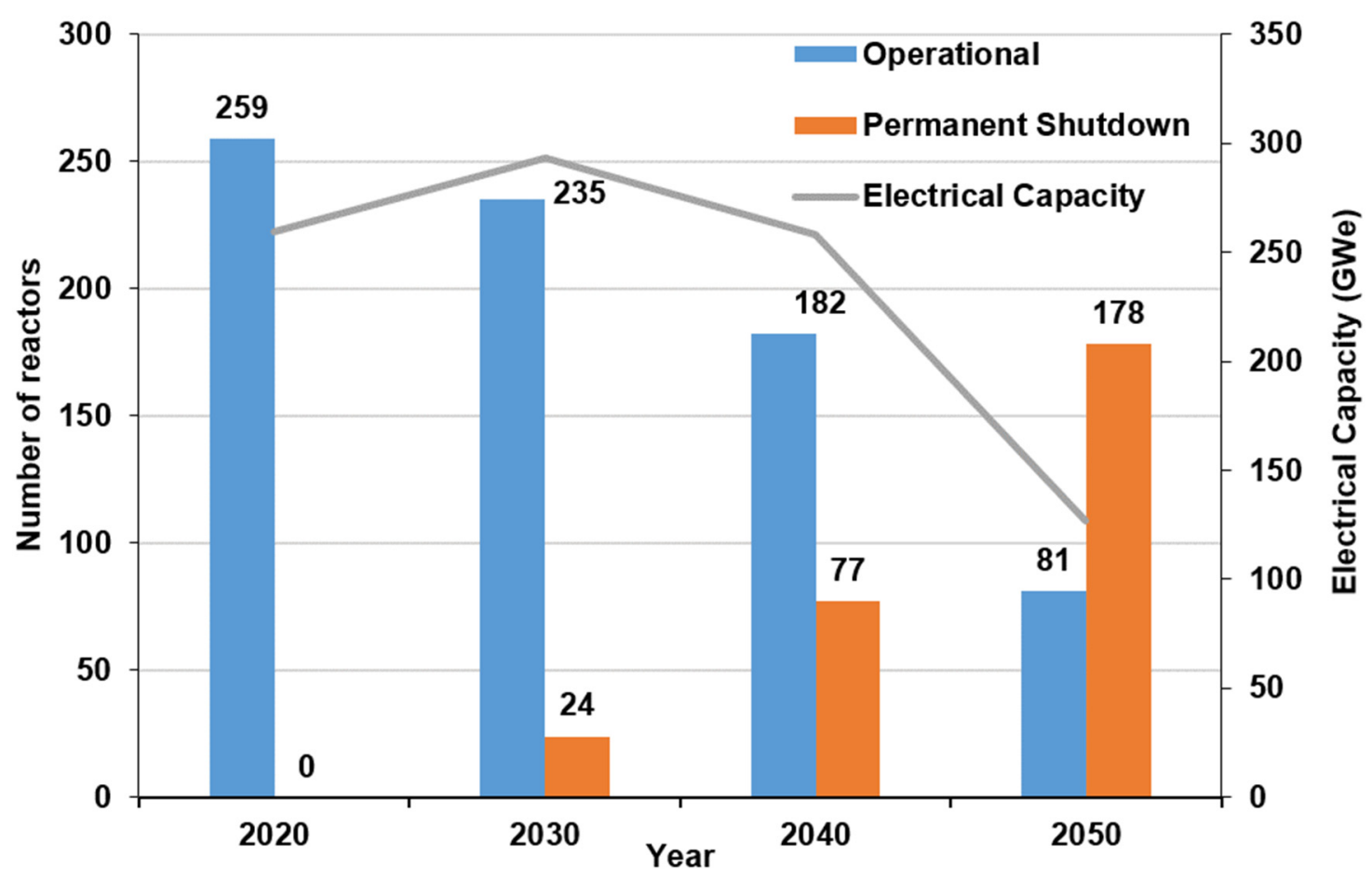

Figure 19. Scenario of life extension of PWR nuclear power plants to 60 years.

R\&D advances of new PWR are reflected in the development of Small Modular Reactor (SMR) technology, still only under development, but not implemented in any nuclear power plant. The SMR technology has two strategic goals: firstly, reduce onsite construction cost and time; secondly, mass manufacturing will make up in economies of volume production what is lost in economies of scale [80]. To achieve this, its design is based on three principles: (i) reactors with a capacity below $300 \mathrm{MWe}$; (ii) small size and standardized main components; (iii) passive safety design [81]. Among the different projects related to the manufacture of SMR, those carried out by NuScale Power and the 
Korea Atomic Energy Research Institute (KAERI) stand out. The SMR designs of these companies are, respectively: (i) the NuScale and (ii) the SMART. The first one, NuScale is an integral pressurized water reactor (iPWR) with seven layers of barriers between fuel and environment. Its rated capacity was raised to $45 \mathrm{MWe}$ of electrical power. On the other hand, the electrical output of SMART could be around 110 MWe and could be use as seawater desalination [80-83].

\section{Conclusions}

Nuclear energy is positioning itself as an alternative to climate change and the problem it poses to humanity. Of the 447 nuclear reactors operating in the world in January 2020, the pressurized water reactor (PWR) has been the most widely deployed nuclear reactor design throughout history, with an operating factor (OF) of $67 \%$.

After years of expansion throughout the 20th century for PWR (Generation II) variants, 300 PWR reactors are currently operating worldwide. Based on the global operating factor (GOF), the North American $(\mathrm{GOF}=31 \%)$ and French $(\mathrm{GOF}=21 \%)$ versions stand out among PWRs. Taking them as a reference, during the 21st century, different oriental PWR designs have been developed. The PWR designs implanted within Generation II evolved to increase their generation capacity. To achieve this, the evolution of the different designs is based on the increase in the size of the main components, i.e., reactor vessel, steam generator and fuel assemblies, as well as the number of reactor coolant system.

Going forward, advances in new PWR designs developed within Generation III and Generation III+ will make these safer and more efficient. These designs, like the Generation IIs, have evolved, increasing both their effectiveness, availability, and generation capacity from a security point of view. This fundamental aspect, the improvement of security, is achieved through an increase in the number of redundancies and including passive security systems.

The under construction factor (UCF) allows us to identify the capacity of implementation of the different PWR designs. Thus, the UCF and expansion mechanism values shown in this article reflect that the Chinese and Russian versions of the PWR design are preferred in under construction nuclear reactors. The Russian and Chinese designs of nuclear reactors PWR, with a global under construction factor (GUCF) greater than $30 \%$ and $20 \%$, respectively, have been characterized both by supplying the demand for nuclear reactors in their home countries, and by having implemented in other Asian countries with growing economies.

In a 60-year life extension scenario, the main Generation II designs will go into permanent shutdown starting in the year 2030. Starting in the year 2030, the start of operation of the Generation III PWR now under construction will mean maintaining capacity of current generation. In 2050, generation capacity will decrease to $127 \mathrm{GWe}$, a $50 \%$ decrease from current generation capacity. Until then, 178 PWRs will be on permanent shutdown and only 81 will be in operation.

The high interest shown throughout the 21st century in SMR technology shows that soon it will be a reality. Taking into account the results shown in this study, which set a 60 -year life extension scenario for PWR nuclear power plants both operative and under construction, the development and commissioning of SMR nuclear power plants would mean maintaining the global impact of the PWR designs in the nuclear industry.

Author Contributions: Conceptualization and methodology, P.F.-A. and D.V.; validation and formal analysis, P.F.-A., D.V. and J.A.O.; data curation, P.F.-A.; Writing-Original Draft Preparation, P.F.-A. and D.V.; writing, review and editing, P.F.-A., D.V. and J.A.O. All authors have read and agreed to the published version of the manuscript.

Funding: This research received no external funding.

Conflicts of Interest: The authors declare no conflict of interest.

\section{References}

1. Meiswinkel, R.; Meyer, J.; Schnell, J. Design and Construction of Nuclear Power Plants; Wilhelm Ernst \& Sohn: Berlin, Germany, 2013; pp. 5-13. 
2. Merk, B.; Litskevich, D.; Whittle, K.R.; Bankhead, M.; Taylor, R.J.; Mathers, D. On a long term strategy for the success of nuclear power. Energies 2017, 10, 867. [CrossRef]

3. Radulescu, L.; Pavelescu, M. Technological transfer from research nuclear reactors to new generation nuclear power reactors. In Proceedings of the 7th International Conference of the Balkan Physical Union, Alexandroupolis, Greece, 9-13 September 2009; Angelopoulos, A., Fildisis, T., Eds.; American Institute of Physics: College Park, MD, USA, 2009; Volume 1203, pp. 1418-1823.

4. Breeze, P. Power Technologies Generation, 2nd ed.; Elsevier: Oxford, UK, 2014; pp. 353-378.

5. Kim, K.T. Evolutionary developments of advanced PWR nuclear materials fuel and cladding materials. Nucl. Eng. Des. 2013, 263, 59-69. [CrossRef]

6. International Atomic Energy Agency. Power Reactor Information System (PRIS). Available online: https: //www.iaea.org/PRIS/home.aspx (accessed on 11 January 2020).

7. Rodriguez-Penalonga, L.; Moratilla-Soria, B.Y. Analysis of the costs of spent nuclear fuel management in Spain: The Mariño model. Energy 2019, 186, 115853. [CrossRef]

8. Csereklyei, Z.; Thurner, P.W.; Bauer, A.; Küchenhoff, H. The effect of economic growth, oil prices, and the benefits of reactor standardization: Duration of nuclear power plant construction revisited. Energ. Policy 2016, 91, 49-59. [CrossRef]

9. Glasstone, S.; Sesonske, A. Nuclear Reactor Engineering: Reactor Systems Engineering; Springer-Science+Business Media: Dordrecht, Germany, 1994; Volume 2, pp. 770-774.

10. Kessides, I.N. The future of the nuclear industry reconsidered: Risks, uncertainties, and continued promise. Energ. Policy 2012, 48, 185-208. [CrossRef]

11. Marques, J.G. Evolution of nuclear fission reactors: Third generation and beyond. Energ. Convers. Manage. 2010, 51, 1774-1780. [CrossRef]

12. Fernández-Arias, P. Análisis de los factores que influyeron en la evolución y desarrollo del reactor nuclear PWR. Ph.D. Thesis, Universidad de Salamanca, Salamanca, Spain, September 2017.

13. Rippon, S. History of the PWR and its worldwide development. Energ. Policy 1984, 12, 259-265. [CrossRef]

14. Nian, V. Global developments in advanced reactor technologies and international cooperation. Energy Procedia 2016, 143, 605-610. [CrossRef]

15. Cummins, W.E.; Matzie, R. Design evolutions of PWRs: Shippingport to generation III+. Prog. Nucl. Energy 2018, 102, 1-29. [CrossRef]

16. Kennard, M.W.; Harbottle, J.E. LWR Control Assembly Designs. A Historical Perspective. Control Assembly Materials for Water Reactors: Experience, Performance and Perspectives; IAEA Tecdoc: Vienna, Austria, 2002; pp. 7-32.

17. Bahman, Z.; McDaniel, P. Thermodynamics in Nuclear Power Plant Systems; Springer Science+Business Media: Cham, Switzerland, 2015; pp. 437-464.

18. Beaver, W. Duquesne Light and Shippingport: Nuclear power is born in western Pennsylvania. West. Pa. Hist. Mag. 1987, 70, 339-358.

19. Basalla, G. The Evolution of Technology; Cambridge University Press: Cambridge, UK, 1988; pp. $100-199$.

20. Burness, H.S.; Montgomey, W.D.; Quirk, J.P. The turnkey era in nuclear power. Land Econ. 1980, 56, 301-327. [CrossRef]

21. Historic American Engineering Record. Haddam Neck Nuclear Power Plant (Connecticut Yankee Nuclear Power Plant); Historic American Engineering Record: Washington, DC, USA, 1968; pp. 3-5.

22. Schneider, R.; Wirtz, P. Adaptation of a pressurized water reactor of American design to the requirements of the German standards program and licensing procedure. Nucl. Eng. Des. 1991, 127, 173-179. [CrossRef]

23. Rebollo, L. A realistic anticipated transient without SCRAM. Evaluation of the Zorita nuclear power plant. Nucl. Tech. 1993, 103, 122-129. [CrossRef]

24. Wang, P.; Chen, Z.; Zhang, R.; Sun, J.; He, Z.; Zhao, F.; Wei, X. Control simulation and study of load rejection transient for AP1000. Prog. Nucl. Energy. 2015, 85, 28-43. [CrossRef]

25. Yang, J.; Liang, R.; Lin, Z.; Huang, X.; Wang, T. Transient analysis of AP1000 NPP under the similar Fukushima accident conditions. Ann. Nucl. Energy 2017, 108, 181-187. [CrossRef]

26. Schulz, T.L. Westinghouse AP1000 advanced passive plant. Nucl. Eng. Des. 2006, 236, 1547-1557. [CrossRef]

27. Wirtz, P. The erection and commissioning Mülheim-Kärlich nuclear power plant. Nucl. Eng. Des. 1987, 100, 297-306. [CrossRef]

28. Green, S.J.; Hetsroni, G. PWR steam generators. Int. J. Multiphas. Flow 1995, 21 (Suppl. 1), 1-97. [CrossRef] 
29. International Atomic Energy Agency. Country Nuclear Power Profiles, France. Available online: https: //cnpp.iaea.org/countryprofiles/France/France.htm (accessed on 23 January 2020).

30. Grubler, A. The cost of the French nuclear scale-up: A case of negative learning by doing. Energ. Policy 2010, 38, 5174-5188. [CrossRef]

31. Grubler, A. An Assessment of the Costs of the French Nuclear PWR Program 1970-2000; International Institute for Applied Systems Analysis: Laxenburg, Austria, 2009; pp. 1-36.

32. Jaquemain, D. Design and operation of a Pressurised Water Reactor Nuclear. In Power Reactor Core Melt Accidents: Current State of Knowledge; IRSN Science and Technology, Series; Jaquemain, D., Ed.; EDP Sciences: Paris, France, 2015; pp. 11-42.

33. Wealer, B.; Bauer, S.; Landry, N.; Seiß, H.; Von Hirschhausen, C. Nuclear Power Reactors Worldwide-Technology Developments, Diffusion Patterns, and Country-by-Country Analysis of Implementation (1951-2017); Deutsches Institut for Wirtschaftsftsforschung: Berlin, Germany, 2012; pp. 94-101.

34. Bonhomme, N. Systems organization for the European pressurized water reactor (EPR). Nucl. Eng. Des. 1999, 187, 71-78. [CrossRef]

35. Teichel, H. Objectives in developing the European pressurized water reactor (EPR). Nucl. Eng. Des. 1996, 165, 271-276. [CrossRef]

36. Semenov, B.A. Nuclear power in the Soviet Union. IAEA Bull. 1983, 25, 47-59.

37. DeLeon, P. Comparative technology and public policy: The development of the nuclear power reactor in six nations. Policy Sci. 1980, 11, 285-307. [CrossRef]

38. Ryzhov, S.B.; Mokhov, V.A.; Nikitenko, M.P.; Bessalov, G.G.; Podshibyakin, A.K.; Anufriev, D.A.; Gado, J.; Rohde, U. VVER-Type reactors of Russian design. In Handbook of Nuclear Engineering; Reactor of Generations III and IV; Cacuci, D.G., Ed.; Springer Science+Business Media: New York, NY, USA, 2010; Volume 4, pp. 2249-2320.

39. Libmann, J. Elements of Nuclear Safety; Les Editions de Physique: Les Ulis, France, 1996; pp. 450-457.

40. Dwiddar, M.S.; Badawi, A.A.; Abou-Gabal, H.H.; El-Osery, I.A. From VVER-1000 to VVER-1200: Investigation of the Effect of the Changes in Core. In Proceedings of the Third International Conference on Physics and Technology of Reactors and Applications, Tetuan, Morocco, 12-14 May 2014.

41. Peachy, C. Chinese Reactor Design Evolution. Nuclear Engineering International. Available online: http://www.neimagazine.com/features/featurechinese-reactor-design-evolution-4272370/ (accessed on 23 January 2020).

42. Wang, Y.; Ma, J.; Fang, Y. Generation III pressurized water reactors and China's nuclear power. J. Zhejiang Univ. Sci. A 2016, 17, 911-922. [CrossRef]

43. Xu, Y.; Kang, J.; Yuan, J. The prospective of nuclear power in China. Sustainability 2018, 10, 2086. [CrossRef]

44. Zheng, M.; Yan, J.; Jun, S.; Tian, L.; Wang, X.; Qiu, Z. The general design and technology innovations of CAP1400. Engineering 2016, 2, 97-102. [CrossRef]

45. Shi, G.; Gu, P.; Lu, W.; Wang, J.; Cao, K.; Zhang, K.; Guo, N. CAP1400 IVR related design features and assessment. Nucl. Eng. Des. 2019, 346, 35-45. [CrossRef]

46. Thomas, S. Is it the end of the line for Light Water Reactor technology or can China and Russia save the day? Energ. Policy 2019, 125, 216-226. [CrossRef]

47. Kadak, A.C. A Comparison of Advanced Nuclear Technologies; Center on Global Energy Policy: New York, NY, USA, 2017.

48. International Atomic Energy Agency. Advanced Large Water Cooled Reactors; Advanced Reactor Information System (ARIS): Vienna, Austria, 2015.

49. Mitenkov, F.M.; Polunichev, V.I. Small nuclear heat and power co-generation stations and water desalination complexes on the basis of marine reactor plants. Nucl. Eng. Des. 1997, 173, 183-191. [CrossRef]

50. Standring, W.J.F.; Dowdall, M.; Amundsen, I.; Strand, P. Floating nuclear power plants: Potential implications for radioactive pollution of the northern marine environment. Mar. Pollut. Bull. 2009, 58, 174-178. [CrossRef]

51. Reinberger, D.; Ajanovic, A.; Haas, R. The technological development of different generations and reactor concepts. In The Technological and Economic Future of Nuclear Power; Hass, R., Mez, L., Ajanovic, A., Eds.; Springer: Wiesbaden, Germany, 2019; pp. 97-115.

52. Xing, J.; Song, D.; Wu, Y. HPR1000: Advanced pressurized water reactor with active and passive safety. Engineering 2016, 2, 79-87. [CrossRef] 
53. Vinod, A. The Expectant Global Nuclear Energy Renaissance: Movers, Shakers and Spoilers. In Resurgence of Nuclear Power: Challenges and Opportunities for Asia; Janardhanan, N., Pant, G., Grover, R.B., Eds.; Springer: Singapore, 2017; pp. 39-70.

54. Greco, A.; Yamamoto, D. Geographical political economy of nuclear power plant closures. Geoforum 2019, 106, 234-243. [CrossRef]

55. Novak, S.; Podest, M. Nuclear power plant aging and life extension: Safety aspects. IAEA Bull. 1987, 4, 31-33.

56. Woo, T.-H.; Lee, U.-C. Safeguard assessment for life extension in nuclear power plants (NPPs) using a production function. Nucl. Eng. Des. 2011, 241, 826-831. [CrossRef]

57. Arel, H.Ş.; Aydin, E.; Kore, S.D. Ageing management and life extension of concrete in nuclear power plants. Powder Technol. 2017, 321, 390-408. [CrossRef]

58. Trampus, P. Role and importance of NDE in nuclear power plant life extension. Procedia Struct. Integrity 2019, 16, 161-168. [CrossRef]

59. Bruck, P.M.; Esselman, T.C.; Elaidi, B.M.; Wall, J.J.; Wong, E.L. Structural assessment of radiation damage in light water power reactor concrete biological shield walls. Nucl. Eng. Des. 2019, 350, 9-20. [CrossRef]

60. Guo, X.; Lai, P.; Li, L.; Tang, L.; Zhang, L. Progress in studying the fretting wear/corrosion of nuclear steam generator tubes. Ann. Nucl. Energy 2020, 144, 107556. [CrossRef]

61. Diercks, D.R.; Shack, W.J.; Muscara, J. Overview of steam generator tube degradation an integrity issues. Nucl. Eng. Des. 1999, 194, 19-30. [CrossRef]

62. Srikantiah, G.; Chappidi, P.R. Particle deposition and fouling in PWR steam generators. Nucl. Eng. Des. 2000, 200, 285-294. [CrossRef]

63. Adamantiades, A.; Kessides, I. Nuclear power for sustainable development: Current status and future prospects. Energ. Policy 2009, 37, 5149-5166. [CrossRef]

64. Verbruggen, A. Belgian nuclear power life extension and fuss about nuclear rents. Energ. Policy 2013, 60, 91-97. [CrossRef]

65. Twilley, R.C., Jr. EPR development-An evolutionary design process. Nucl. News 2004, 47, $26-30$.

66. Friedman, B. The AP1000 plant and the China commissioning success. ASME Nucl. Eng. Rad. Sci. 2019, 5, 1-3. [CrossRef]

67. León, P.T.; Cuesta, L.; Serra, E.; Yagüe, L. Life Extension of Nuclear Power Plants: World Situation and the USA Case. Rev. Gén. Nucl. 2010, 6, 50-56. [CrossRef]

68. Kerasmi, A.; Moroni, J.M. Consquences of the Fukushima accident for the life extension program of French nuclear power plants. In Proceedings of the Third International Conference on Nuclear Power Plant Life Management (IAEA), Salt Lake City, UT, USA, 14-18 May 2012.

69. Cenerino, G.; Dubreuil, M.; Raimond, E.; Pichereau, F. Radiological objectives and severe accident mitigation strategy for the generation II PWRs in France in the framework of PLE. In Proceedings of the Third International Conference on Nuclear Power Plant Life Management (IAEA), Salt Lake City, UT, USA, 14-18 May 2012.

70. Ramana, M.V. Second life or half-life? The contested future of nuclear power and its potential role in a sustainable energy transition. In Energy Transitions; Kern, F., Ed.; Palgrave Macmillan: London, UK, 2016; pp. 363-396.

71. Morgan, M.G.; Abdulla, A.; Ford, M.J.; Rath, M. US nuclear power. The vanishing low-carbon wedge. Proc. Natl. Acad. Sci. USA 2018, 115, 7184-7189. [CrossRef]

72. International Atomic Energy Agency. Nuclear Power Reactors in the World; International Atomic Energy Agency: Vienna, Austria, 2019; pp. 78-79.

73. Garamszeghy, M. Nuclear Fuel Waste Projections in Canada-2013 Update; Nuclear Waste Management Organization: Toronto, ON, Canada, 2013; pp. 4-10.

74. Sheffield, R.; Pitcher, E. Application of accelerators in nuclear waste management. ICFA Beam Dyn. Newsl. 2009, 49, 16-38.

75. Yanagihara, S. A study on decision-making methodology for decommissioning/life extension of nuclear power plant. In Proceedings of the 7th Symposium on Power and Energy Systems, Tokyo, Japan, 21 October-1 November 2000; pp. 345-349.

76. Ramana, M.V. Technical and social problems of nuclear waste. Wires Energ. Environ. 2018, 7, e289. [CrossRef] 
77. Volk, R.; Felix, H.; Hünlich, T.; Schultmann, F. The future of nuclear decommissioning-A worldwide market potenical. Energ. Policy 2019, 124, 226-261. [CrossRef]

78. International Atomic Energy Agency. Opportunities for Cogeneration with Nuclear Energy; IAEA Nuclear Energy Series NP-T-4.1; International Atomic Energy Agency: Vienna, Austria, 2017; pp. 22-24.

79. Nguyen, H.D.; Alpy, N.; Haubensack, D.; Barbier, D. Insight on electrical and thermal powers mix with a Gen2 PWR: Rankine cycle performances under low to high temperature grade cogeneration. Energy 2020, 202, 117518. [CrossRef]

80. Makhijani, A. Light Water Design of Small Modular Reactors: Facts and Analysis; Institute for Energy and Environmental Research: Takoma Park, MD, USA, 2013; pp. 39-70.

81. Cooper, M. Small modular reactors and the future of nuclear power in the United States. Energ. Res. 2014, 3, 161-177. [CrossRef]

82. Arda, S.E.; Holbert, K.E. A dynamic model of a passively cooled small modular reactor for controller design purposes. Nucl. Eng. Des. 2015, 289, 218-230. [CrossRef]

83. Liu, Z.; Fan, J. Technology readiness assessment of Small Modular Reactor (SMR) designs. Prog. Nucl. Energ. 2014, 70, 20-28. [CrossRef]

(C) 2020 by the authors. Licensee MDPI, Basel, Switzerland. This article is an open access article distributed under the terms and conditions of the Creative Commons Attribution (CC BY) license (http://creativecommons.org/licenses/by/4.0/). 